\title{
Neogenin in Amygdala for Neuronal Activity and Information Processing
}

\author{
(DXiang-Dong Sun, ${ }^{1,4 \star}$ Wen-Bing Chen, ${ }^{2,3,4 \star}$ Dong Sun, ${ }^{2,4 \star}$ Jie Huang, ${ }^{1}$ Yuan-Quan Li, ${ }^{1}$ Jin-Xiu Pan,,${ }^{2,4}$ Ya-Nan Wang, ${ }^{7}$ \\ Kai Zhao, ${ }^{2,4}$ Zhao-Qi Dong, ${ }^{2,4}$ Hong-Sheng Wang, ${ }^{2,4}{ }^{\oplus}$ Lei Xiong, ${ }^{2,4}$ Aiguo Xuan, ${ }^{1}$ Shen-Ting Zhao, ${ }^{1}{ }^{\circledR}$ Anilkumar Pillai, ${ }^{5}$ \\ Wen-Cheng Xiong, ${ }^{2,4,6}$ and Lin $\mathrm{Mei}^{2,3,4,6}$ \\ ${ }^{1}$ School of Basic Medical Sciences, Second Affiliated Hospital of Guangzhou Medical University, Guangzhou 510260, China, ${ }^{2}$ Department of Neurosciences, \\ School of Medicine, Case Western Reserve University, Cleveland, Ohio 44106, ${ }^{3}$ Institute of Life Science, Nanchang University, Nanchang 330031, China, \\ ${ }^{4}$ Department of Neuroscience and Regenerative Medicine, Medical College of Georgia, Augusta University, Augusta, Georgia 30912, ${ }^{5}$ Department of \\ Psychiatry, Medical College of Georgia, Augusta University, Augusta, Georgia 30912, ${ }^{6}$ Louis Stokes Cleveland Veterans Affairs Medical Center, Cleveland, \\ Ohio 44106, and ${ }^{7}$ Department of Pathology, University of Texas Southwestern Medical Center, Dallas, Texas 75390
}

Fear learning and memory are vital for livings to survive, dysfunctions in which have been implicated in various neuropsychiatric disorders. Appropriate neuronal activation in amygdala is critical for fear memory. However, the underlying regulatory mechanisms are not well understood. Here we report that Neogenin, a DCC (deleted in colorectal cancer) family receptor, which plays important roles in axon navigation and adult neurogenesis, is enriched in excitatory neurons in BLA (Basolateral amygdala). Fear memory is impaired in male Neogenin mutant mice. The number of $\mathrm{cFos}^{+}$neurons in response to tone-cued fear training was reduced in mutant mice, indicating aberrant neuronal activation in the absence of Neogenin. Electrophysiological studies show that Neogenin mutation reduced the cortical afferent input to BLA pyramidal neurons and compromised both induction and maintenance of Long-Term Potentiation evoked by stimulating cortical afferent, suggesting a role of Neogenin in synaptic plasticity. Concomitantly, there was a reduction in spine density and in frequency of miniature excitatory postsynaptic currents (mEPSCs), but not miniature inhibitory postsynaptic currents, suggesting a role of Neogenin in forming excitatory synapses. Finally, ablating Neogenin in the BLA in adult male mice impaired fear memory likely by reducing mEPSC frequency in BLA excitatory neurons. These results reveal an unrecognized function of Neogenin in amygdala for information processing by promoting and maintaining neurotransmission and synaptic plasticity and provide insight into molecular mechanisms of neuronal activation in amygdala.

Key words: amygdala; fear memory; Neogenin; synaptic transmission

Significance Statement

Appropriate neuronal activation in amygdala is critical for information processing. However, the underlying regulatory mechanisms are not well understood. Neogenin is known to regulate axon navigation and adult neurogenesis. Here we show that it is critical for neurotransmission and synaptic plasticity in the amygdala and thus fear memory by using a combination of genetic, electrophysiological, behavioral techniques. Our studies identify a novel function of Neogenin and provide insight into molecular mechanisms of neuronal activation in amygdala for fear processing.

\section{Introduction}

Fear learning is a vital process for animals to survive by generating appropriate behaviors, such as fleeing, hiding, or freezing from perceived traumatic events (Olsson and Phelps, 2007). Dysfunctions in fear memory processing have been implicated in various neuropsychiatric disorders, including post-traumatic

\footnotetext{
Received Feb. 16, 2018; revised Sept. 4, 2018; accepted Sept. 6, 2018.

Author contributions: X.-D.S. wrote the first draft of the paper; W.-C.X. and L.M. edited the paper; X.-D.S., W.-C.X., and L.M. designed research; X.-D.S., W.-B.C., D.S., J.H., Y.-Q.L., J.-X.P., Y.-N.W., K.Z., Z.-Q.D., H.-S.W., L.X., A.X., and S.-T.Z. performed research;X.-D.S., W.-B.C.,D.S., and A.P. analyzed data; W.-C.X. and L.M. wrote the paper.

This work was supported in part by National Institutes of Health Grants MH083317, NS082007, and NS090083 to L.M., and Grants AG051773 and AG045781 to W.-C.X., Veteran Administration 1/01IBX001020A to L.M., and Guangzhou Medical University Startup B185006002009 to X.-D.S. We thank members of L.M. and W.-C.X. laboratories for helpful discussions and suggestions.
}

The authors declare no competing financial interests.

${ }^{*}$ X.-D.S., W.-B.C., and D.S. contributed equally to this work.

Correspondence should be addressed to either of the following: Dr. Xiang-Dong Sun, School of Basic Medical Sciences, Second Affiliated Hospital of Guangzhou Medical University, Guangzhou 510260, China, E-mail: douba00512@126.com; or Dr. Wen-Cheng Xiong, Department of Neurosciences, School of Medicine, Case Western Reserve University, Cleveland, Ohio 44106, E-mail: wen-cheng.xiong@case.edu.

DOI:10.1523/JNEUROSCI.0433-18.2018

Copyright $\odot 2018$ the authors $\quad 0270-6474 / 18 / 389600-14 \$ 15.00 / 0$ 
stress disorder, schizophrenia, and addiction (Torregrossa et al., 2011; Bolton et al., 2012; Parsons and Ressler, 2013). In rodents, fear learning models can be achieved with classical auditory fear conditioning by pairing a neutral auditory stimulus (conditioned stimulus [CS]) with an aversive footshock (unconditioned stimulus [US]). It is well established that the amygdala is a critical brain region for formation and storage of fear memory (LeDoux, 2000; McGaugh, 2004; Phelps and LeDoux, 2005). The amygdala, located in the medial temporal lobes of the brain, consists of a group of nuclei. The BLA (basolateral amygdala) integrates sensory inputs from the thalamus and cortex and sends projections to the CeA (Central amygdala) and, eventually, the brainstem and hypothalamus to elicit an appropriate response (Sah et al., 2003; Izquierdo et al., 2016). However, how fear memory is allocated to neurons in the amygdala remains unclear.

The majority of neurons $(80 \%-85 \%)$ in the BLA are excitatory neurons (McDonald, 1996; Sah et al., 2003). Upon fear conditioning training, a subset of excitatory neurons in the BLA is activated, which could be identified by elevated expression of the immediate early gene cFos (Knapska et al., 2007). These activated neurons are considered to form a unique memory trace (Kim et al., 2014; Tovote et al., 2015). Aberrant neuronal activation in the amygdala leads to impaired fear memory; and disinhibition of the amygdala facilitates fear expression in mice (Huang et al., 2014; Liu et al., 2017). Nevertheless, underlying mechanisms regarding how neuronal activation is regulated in the amygdala are not well understood.

Neogenin, a Type I transmembrane protein of the DCC (deleted in colorectal cancer) family, was identified as a receptor for the axon guidance cue netrin- 1 as well as repulsive guidance molecules (Vielmetter et al., 1994; Rajagopalan et al., 2004; De Vries and Cooper, 2008; Xu et al., 2014). Recent data suggest that Neogenin has diverse functions in various organs, such as endochondral bone formation (Zhou et al., 2010), neural tube formation (Kee et al., 2008), digit patterning (Hong et al., 2012), ion metabolism (Kuns-Hashimoto et al., 2008; Lee et al., 2010), and muscle differentiation (Kang et al., 2004). Neogenin is expressed in embryonic and adult neural stem cells (Fitzgerald et al., 2007; Bradford et al., 2010; van den Heuvel et al., 2013) and has been implicated in adult neurogenesis (O'Leary et al., 2015; Huang et al., 2016; Sun et al., 2018). Interestingly, Neogenin is known expressed in adult brains (van den Heuvel et al., 2013; Huang et al., 2016); however, its functions in developed neural circuits remain largely unknown.

Here we provide evidence that Neogenin is required for information processing in amygdala. Neogenin was highly expressed in excitatory neurons in the BLA. Brain-selective conditional mutation impaired fear memory. We explored underlying mechanisms of how Neogenin regulates the function of the amygdala by using a combination of genetic, electrophysiological, and behavioral techniques. We found that Neogenin is critical for neuronal activation in the amygdala. In the absence of Neogenin, the cortical afferent input and plasticity were compromised, associated with reduced spine density and mEPSC (miniature excitatory currents) frequency. Moreover, Neogenin ablation in adult mice impairs neurotransmission and fear memory. These results reveal an unrecognized function of Neogenin in amygdala for information processing by regulating neurotransmission and synaptic plasticity, and provide insight into molecular mechanisms of neuronal activation in amygdala.

\section{Materials and Methods}

Reagents and antibodies. Chemicals were purchased from Sigma-Aldrich unless otherwise indicated. DL-AP5 (0105), CNQX (0190), and Bicuculline (BMI, 0130) were purchased from Tocris Bioscience. Information of antibodies was as follows: rabbit anti-Neogenin (1:1000 for blotting); chicken anti- $\beta$-gal (Abcam) (ab9361; 1:1000 for staining); mouse monoclonal anti-Camkii (Santa Cruz Biotechnology) (sc-5306; 1:100 for staining); mouse anti-NeuN (EMD Millipore) (MAB377; 1:500 for staining); rabbit anti- $\beta$-actin (EMD Millipore) (04-1116; 1:4000 for blotting); rabbit anti-parvalbumin (PV) (Swant) (PV25; 1:1000 for staining); mouse monoclonal anti-cFos (Santa Cruz Biotechnology) (sc-271243; 1:500 for staining); chicken anti-GFP (Aves) (GFP-10120; 1:2000 for staining); mouse anti-PSD-95 (Synaptic Systems) (124011; 1:1000 for blotting); and rabbit anti-synaptophysin (Abcam) (ab32127; 1:5000 for blotting).

Animals. Male mice at age of 2-3 months were used for the experiments. Mouse strains were described previously: Neogenin-Lacz reporter mice (Neogenin-Lacz ${ }^{+/-}$) (Mitchell et al., 2001; Huang et al., 2016); Neogenin-floxed mice(Neo ${ }^{f / f}$ ) (Huang et al., 2016); GFAP-Cre (Zhuo et al., 2001; Sun et al., 2016); tdTomato ( td $^{+}$) (Ai9 from The Jackson Laboratory, \#007909); and GAD67-GFP (Tamamaki et al., 2003; Lu et al., 2014). All of the mouse lines were confirmed by genotyping analysis with PCR and by Western blot analysis for the loss of Neogenin expression. Genotyping primer sequences were as follows: Neogenin-Lacz, 5'-GGG TCT CTT TGT GAG GGT CAC-3' and 5'-GCT CTT TTC AGT AGG CTC TCT GC-3'; Neo ${ }^{f / f}, 5^{\prime}$-CGG CTG TTT GTA CCC TCG TGT GG-3' and 5'-GTC GCA TCA GAA ATA CCA AGT CTA G-3'; GFAP::Cre, 5'-ACT CCT TCA TAA AGC CCT-3' and 5' -GCC AGC TAC GTT GCT CAC TA- $3^{\prime}$; tdTomato, $5^{\prime}$-CTG TTC CTG TAC GGC ATG G-3' and 5'-GGC ATT AAA GCA GCG TAT CC-3'; GAD67-GFP, 5' -GGC ACA GCT CTC CCT TCT GTT TGC-3' and $5^{\prime}$-CTC TCC TTT CGC GTT CCG ACA G-3' and 5' -CTG CTT GTC GGC CAT GAT ATA GAC G-3'. In all studies, at least three pairs of mice from the same litters were used. Significant efforts are also made to minimize the total number of animals used while maintaining statistically valid group numbers. Mice for experiments were group-housed no more than 5 per cage in a room with a $12 \mathrm{~h}$ light/dark cycle with ad libitum access to water and rodent chow diet (Diet 1/4" 7097, Harlan Teklad). Experiments with animals were approved by the Animal Ethics Committee of Guangzhou Medical University and the Institutional Animal Care and Use Committee of Case Western Reserve University School of Medicine.

Brain morphological analysis. For X-gal assay, anesthetized mice were perfused transcardially with $4 \%$ PFA in PBS, and brains were quickly isolated and fixed in $4 \% \mathrm{PFA}$ at $4^{\circ} \mathrm{C}$ for $2 \mathrm{~h}$. Coronal sections were cut at $50 \mu \mathrm{m}$ interval by vibratome (VT-1200S, Leica Microsystems) and mounted on slides. After washing with PBS for 3 times, sections were stained in X-gal solution ( $1 \mathrm{mg} / \mathrm{ml} \mathrm{X-gal,} 5 \mathrm{~mm} \mathrm{K3Fe}(\mathrm{CN}) 6,5 \mathrm{~mm}$ $\mathrm{K} 4 \mathrm{Fe}(\mathrm{CN}) 6,0.02 \% \mathrm{NP}-40,0.01 \%$ deoxycholate, and $2 \mathrm{~mm} \mathrm{MgCl}_{2}$ in $\mathrm{PBS})$ at $37^{\circ} \mathrm{C}$ for $2 \mathrm{~h}$. They were then washed in PBS for 3 times, counterstained with nuclear Fast Red (Vector Laboratories, H-3403), mounted in CC/Mount (Sigma-Aldrich), and sealed with coverslips. Images were taken by BZ-X700 fluorescence microscope (Keyence). In the experiment of external capsule (EC) and anterior commissure (AC) tracts comparison, sections were processed as described above, except the step of X-gal solution incubation.

For immunofluorescence staining, as reported previously (Ou et al., 2018), anesthetized mice were perfused transcardially with $4 \%$ PFA in PBS and tissues were fixed in $4 \%$ PFA at $4^{\circ} \mathrm{C}$ for $8 \mathrm{~h}$. After dehydration by $30 \%$ sucrose, brain blocks were frozen and cut into $30-\mu \mathrm{m}$-thick sections on cryostat (HM550; Thermo Fisher Scientific). Sections were permeabilized with $0.3 \%$ Triton X-100 and 5\% BSA in PBS and incubated with primary antibodies at $4^{\circ} \mathrm{C}$ overnight. After washing with PBS for 3 times, samples were incubated with AlexaFluor-conjugated secondary antibodies (1:1000, Invitrogen, donkey anti-mouse AlexaFluor-555 for Camkii and cFos staining; donkey anti-mouse AlexaFluor-555 or -647 for NeuN staining; donkey anti-rabbit AlexaFluor- 488 for PV staining; goat antichicken AlexaFluor- 488 or -555 for $\beta$-gal staining; and goat anti-chicken AlexaFluor-488 for GFP staining) for $1 \mathrm{~h}$ at room temperature. Samples were mounted with Vectashield mounting medium (Vector Laborato- 
ries), and images were taken by LSM510 confocal microscope (Carl Zeiss). In some experiments, $1.5 \mathrm{~h}$ before perfusion, mice were subject to fear conditioning training (see methods below).

Slice preparation. Amygdala slices were prepared as described previously (Lu et al., 2014; Zhang et al., 2016). Briefly, male mice (2-3 months) were anesthetized by intraperitoneal injection with ketamine/xylazine (Sigma-Aldrich, 100/20 mg/kg, respectively), brains were quickly removed and chilled in ice-cold modified ACSF containing the following (in mM as follows: 220 sucrose, $2 \mathrm{KCl}, 10 \mathrm{MgSO}_{4}, 0.2 \mathrm{CaCl}_{2}, 1.3$ $\mathrm{NaH}_{2} \mathrm{PO}_{4}, 26 \mathrm{NaHCO}_{3}$, and 10 glucose). Coronal amygdala slices (300 $\mu \mathrm{m})$ were cut in ice-cold modified ACSF using a VT-1200S vibratome (Leica Microsystems) and transferred to a storage chamber containing regular ACSF (in mM as follows: $126 \mathrm{NaCl}, 3 \mathrm{KCl}, 1 \mathrm{MgSO}_{4}, 2 \mathrm{CaCl}_{2}, 1.25$ $\mathrm{NaH}_{2} \mathrm{PO}_{4}, 26 \mathrm{NaHCO}_{3}$, and 10 glucose) at $34^{\circ} \mathrm{C}$ for $30 \mathrm{~min}$ and at room temperature $\left(25 \pm 1^{\circ} \mathrm{C}\right)$ for additional $1 \mathrm{~h}$ before recording. All solutions were saturated with $95 \% \mathrm{O}_{2} / 5 \% \mathrm{CO}_{2}(\mathrm{v} / \mathrm{v})$.

Electrophysiological recording. Slices were placed in the recording chamber, which was superfused $(2 \mathrm{ml} / \mathrm{min})$ with ACSF at $32^{\circ} \mathrm{C}-34^{\circ} \mathrm{C}$. Whole-cell patch-clamp recordings from excitatory neurons in BLA were visualized with infrared optics using an upright microscope equipped with a $40 \times$ water-immersion lens (Axioskop 2 Plus, Carl Zeiss) and infrared-sensitive CCD camera (C2400-75, Hamamatsu). Excitatory neurons were identified by pyramidal shape and spike frequency adaptation induced by prolonged depolarizing current injection. The pipettes were pulled by a micropipette puller (P-97, Sutter Instruments) with a resistance of 3-5 $\mathrm{m} \Omega$. Recordings were made with MultiClamp $700 \mathrm{~B}$ amplifier and 1440A digitizer (Molecular Devices).

To detect electric property of excitatory neurons in BLA, they were current-clamped and measured by injecting a series of depolarizing pulses (from 50 to $110 \mathrm{pA}$ at a step of $10 \mathrm{pA}$ ) in the presence of $20 \mu \mathrm{M}$ CNQX, $100 \mu \mathrm{M}$ DL-AP5, and $20 \mu \mathrm{M}$ BMI, with the pipette solution containing the following (in $\mathrm{mM}$ ): $125 \mathrm{~K}$-gluconate, $5 \mathrm{KCl}, 10$ HEPES, 0.2 EGTA, $1 \mathrm{MgCl}_{2}, 4 \mathrm{Mg}$-ATP, $0.3 \mathrm{Na}-\mathrm{GTP}$, and 10 phosphocreatine, $\mathrm{pH}$ 7.40 (285 mOsm). Membrane input resistance was calculated in response to a series of hyperpolarizing pulses.

Evoked EPSCs (eEPSCs) were recorded from excitatory neurons at holding potential of $-70 \mathrm{mV}$, in response to stimulations with gradual intensities. Stimulations were delivered by a concentric bipolar electrode (FHC), which was placed on the cortical pathway. eEPSCs were recorded in the presence of $20 \mu \mathrm{M} \mathrm{BMI}$, with the pipette solution containing the following (in $\mathrm{mM}$ ): $125 \mathrm{Cs}$-methanesulfonate, $5 \mathrm{CsCl}, 10 \mathrm{HEPES}, 0.2$ EGTA, $1 \mathrm{MgCl}_{2}$, $4 \mathrm{Mg}$-ATP, $0.3 \mathrm{Na}$-GTP, 10 phosphocreatine, and 5 QX314, pH 7.40 (285 mOsm). For paired-pulse ratio (PPR) recording, the first eEPSC was adjusted with amplitude between 100 and $150 \mathrm{pA}$. Interval of paired stimulations was set 25,50 , and $100 \mathrm{~ms}$, respectively. Value of ratios was defined as $[(p 2 / p 1] \times 100$, where $p 1$ and $p 2$ are the amplitude of the EPSCs evoked by the first and second pulse, respectively.

LTP was recorded in whole-cell configuration as described previously (Liu et al., 2017). Briefly, eEPSCs of 100-150 pA were recorded with stimulations of cortical input pathway. After at least 6 min baseline recording, 100 presynaptic stimuli at $2 \mathrm{~Hz}$ were delivered while excitatory neurons were held at $30 \mathrm{mV}$. LTP was quantified by normalizing the data collected in last 5 min to mean values of baseline eEPSC amplitudes.

For mEPSC recording, excitatory neurons were held at $-70 \mathrm{mV}$ in the presence of $20 \mu \mathrm{M}$ BMI and $1 \mu \mathrm{M}$ TTX, with the pipette solution containing the following (in mM): 125 Cs-methanesulfonate, $5 \mathrm{CsCl}, 10 \mathrm{HEPES}$, 0.2 EGTA, $1 \mathrm{MgCl}_{2}, 4 \mathrm{Mg}$-ATP, $0.3 \mathrm{Na}$-GTP, 10 phosphocreatine, and 5 QX314, pH 7.40 (285 mOsm). mIPSCs were recorded at $-70 \mathrm{mV}$ in the presence of $20 \mu \mathrm{M}$ CNQX, $100 \mu \mathrm{M}$ DL-AP5, and $1 \mu \mathrm{M}$ TTX, with the pipette solution containing the following (in $\mathrm{mM}$ ): $140 \mathrm{CsCl}, 10 \mathrm{HEPES}$, 0.2 EGTA, $1 \mathrm{MgCl}_{2}, 4 \mathrm{Mg}$-ATP, $0.3 \mathrm{Na}$-GTP, 10 phosphocreatine, and 5 QX314, pH 7.40 (285 mOsm).

To perform double-patch recordings, pairs of excitatory neurons with red fluorescence $\left(\mathrm{Cre}^{+}\right)$and adjacent nonfluorescent $\left(\mathrm{Cre}^{-}\right)$excitatory neurons were recorded with the pipette solution containing the following (in mM): $125 \mathrm{~K}$-gluconate, $5 \mathrm{KCl}, 10 \mathrm{HEPES}, 0.2 \mathrm{EGTA}, 1 \mathrm{MgCl}_{2}, 4$ Mg-ATP, $0.3 \mathrm{Na}$-GTP, and 10 phosphocreatine, pH 7.40 (285 mOsm). Only excitatory neurons were chosen for recording, which were identified by pyramidal shape and spike frequency adaptation. Cortical afferent fibers were stimulated at intensities set to induce eEPSCs of 100-200 pA for $\mathrm{Cre}^{-}$neurons. AMPAR-mediated eEPSCs were recorded at holding potential of $-70 \mathrm{mV}$ in the presence of $20 \mu \mathrm{M} \mathrm{BMI}$, holding potential was then switched to $40 \mathrm{mV}$ to record NMDAR-mediated eEPSCs. AMPAR and NMDAR current were measured as the peak amplitudes and $50 \mathrm{~ms}$ after the peak amplitude, respectively.

In all experiments, series resistance was controlled $<20 \mathrm{M} \Omega$ and not compensated. Cells would be rejected if membrane potentials were more positive than $-60 \mathrm{mV}$; or if series resistance fluctuated $>20 \%$ of initial values. All recordings were done at $32^{\circ} \mathrm{C}-34^{\circ} \mathrm{C}$. Data were filtered at 1 $\mathrm{kHz}$ and sampled at $10 \mathrm{kHz}$.

Subcellular fractionation. Subcellular fractions were prepared as described previously (Wan et al., 2017; Wang et al., 2018). Briefly, tissues were collected from adult male mice and homogenized in $10 \mathrm{vol}$ of HEPES-buffered sucrose (0.32 м sucrose, 4 mm HEPES/NaOH, pH 7.4). Supernatant (S1) was collected after centrifugation at $1000 \times g$ for 10 min to remove nuclear and other cell debris. $S 1$ fraction was centrifuged at $10,000 \times g$ for 15 min to obtain the crude synaptosomal fraction (P2) and supernatant (S2). P2 pellet was resuspended in water for hypoosmotic shock for $<10 \mathrm{~s}$, which was rapidly adjusted to 4 mM HEPES and incubated on a rotator at $4^{\circ} \mathrm{C}$ for $30 \mathrm{~min}$. Resuspended P2 was centrifuged at $25,000 \times g$ for 20 min to yield the supernatant (S3, crude synaptic vesicle fraction) and pellet (P3, synaptosomal membrane fraction). $\mathrm{S} 3$ fraction was centrifuged at $160,000 \times \mathrm{g}$ at $4^{\circ} \mathrm{C}$ for $60 \mathrm{~min}$ to yield the pellet that was enriched with synaptic vesicle proteins (SV fraction). P3 pellet was resuspended in HEPES-buffered sucrose, carefully layered on top of a discontinuous gradient containing $0.8,1.0$, and $1.2 \mathrm{M}$ sucrose (top to bottom), and centrifuged at $150,000 \times g$ at $4^{\circ} \mathrm{C}$ for $2 \mathrm{~h}$. The gradient yielded a floating myelin fraction ( $\mathrm{G} 1$, the top layer), a light membrane fraction at the $0.8 \mathrm{M} / 1.0 \mathrm{~m}$ sucrose interface (G2), and a synaptosomal plasma membrane fraction at the $1.0 \mathrm{M} / 1.2 \mathrm{M}$ sucrose interface (G3). The G3 fraction was incubated with $1 \%$ Triton X-100 in $50 \mathrm{~mm}$ HEPES/NaOH, $\mathrm{pH} 8.0$, at $4^{\circ} \mathrm{C}$ for $30 \mathrm{~min}$ and subjected to centrifugation at $25,000 \times g$ for $1 \mathrm{~h}$ to yield the supernatant (presynaptic membrane fraction) and the pellet (postsynaptic membrane fraction). All procedures were performed at $4^{\circ} \mathrm{C}$, and buffers or solutions contained protease inhibitors and phosphatase inhibitors $(50 \mathrm{~mm} \mathrm{NaF}, 1 \mathrm{~mm}$ sodium orthovanadate, $20 \mathrm{~mm} \beta$-glycerophosphate).

Protein assay and Western blotting analysis. Protein concentrations were measured using Pierce BCA Protein Assay Kit (23225, Thermo Fisher Scientific). Absorbance was measured using a microplate reader (BioTek, Synergy HTX). Protein concentration in samples was calculated based on a calibration curve from known concentrations of BSA samples.

Western blots were performed as described previously (Dong et al., 2014; Huang et al., 2016; Sun et al., 2016). In brief, homogenates of brain tissues were prepared in RIPA buffer containing the following (in $\mathrm{mM}$ ): 50 Tris- $\mathrm{HCl}, \mathrm{pH}$ 7.4, $150 \mathrm{NaCl}, 2 \mathrm{EDTA}, 1 \mathrm{PMSF}, 50$ sodium fluoride, 1 sodium vanadate, 1 DTT with $1 \%$ sodium deoxycholate, $1 \%$ SDS, and $1 \%$ protease inhibitors cocktails. Samples (30 $\mu \mathrm{g}$ of protein) were resolved on SDS-PAGE and transferred to nitrocellulose membranes, which were incubated in the TBS buffer containing $0.1 \%$ Tween 20 and $5 \%$ milk for $1 \mathrm{~h}$ at room temperature before the addition of primary antibody for incubation overnight at $4^{\circ} \mathrm{C}$. After wash, membranes were incubated with HRP-conjugated secondary antibody (Invitrogen) in same TBS buffer for $1 \mathrm{~h}$ at room temperature. Immunoreactive bands were visualized using enhanced chemiluminescence (Pierce). Films were scanned with an Epson 1680 scanner and analyzed with ImageJ (National Institutes of Health). Band density of interested proteins was normalized in relation to loading control.

Golgi staining. Golgi staining was performed following the manufacturer's protocol (FD Rapid GolgiStain Kit, FD NeuroTechnologies) as described previously (Sun et al., 2016; Zhang et al., 2017). Briefly, brain tissues were incubated in mixed solutions A and B for 2 weeks in dark at room temperature and put into solution $\mathrm{C}$ for $3 \mathrm{~d}$. The $100-\mu \mathrm{m}$-thick slices were cut and stained with solutions $\mathrm{D}$ and $\mathrm{E}$, dehydrated in gradient ethanol solutions, cleared with xylene, and mounted on slides for imaging. Images of neurons were randomly taken from BLA sections and imported into ImageJ for analysis. Spines of secondary and tertiary dendritic branches of randomly selected segments ( $20 \mu \mathrm{m}$ each) were quan- 
A
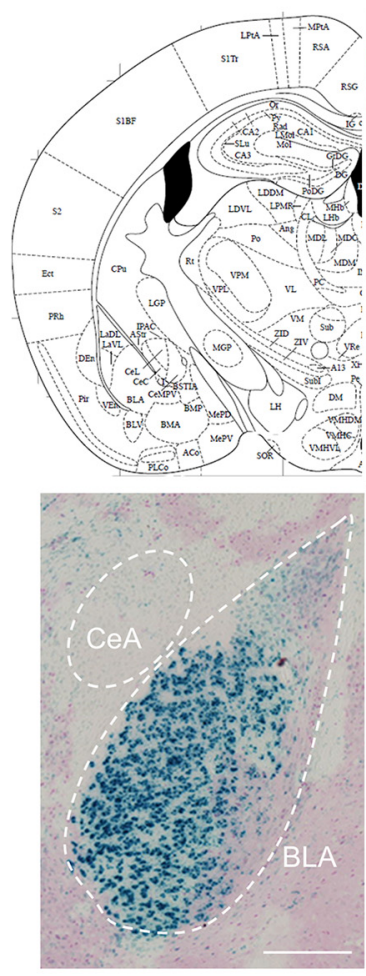

B

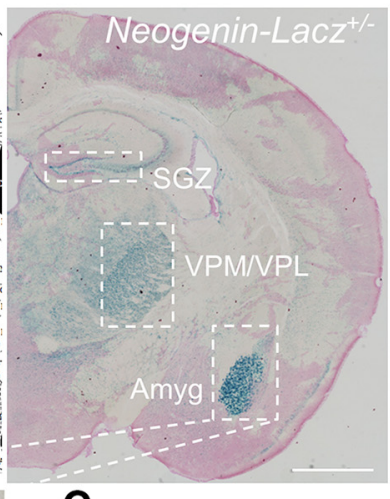

C
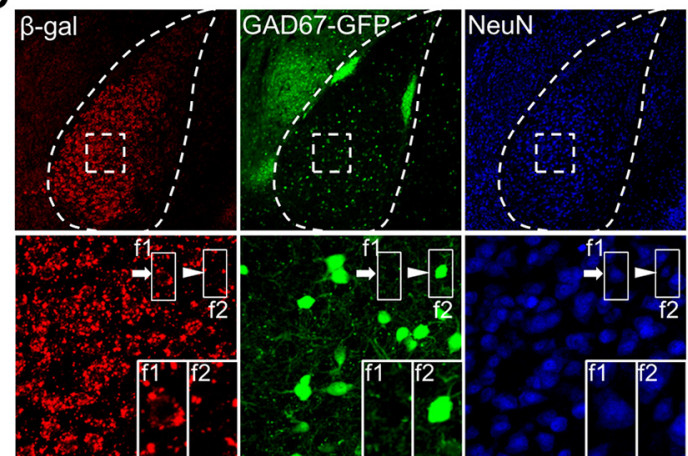
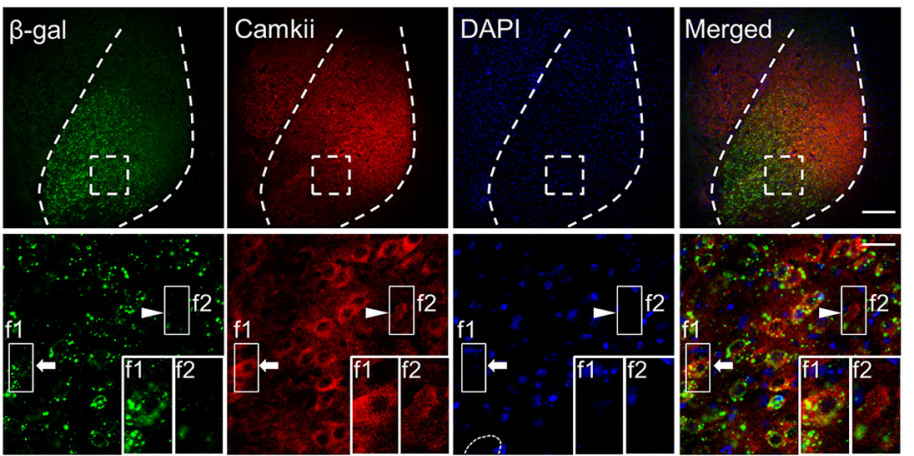
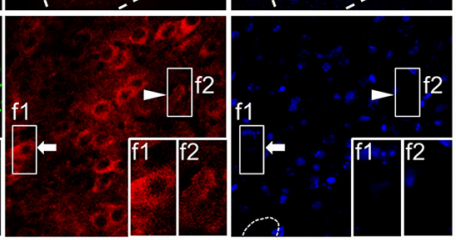

\section{D}
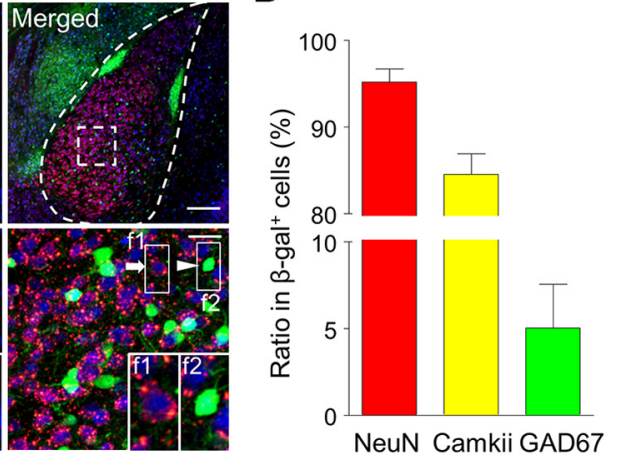

Figure 1. Enriched expression of Neogenin in excitatory neurons in BLA. $A$, Enriched $\beta$-gal activity in BLA, SGZ, and VPM/VPL, but not in CeA. Top left, Diagram of coronal section. Top right, X-gal staining of brain slice of Neogenin-Lacz heterozygous mice. Bottom, Enlarged image of amygdala (amyg). Scale bars: Top, $1 \mathrm{~mm} ;$; Bottom, $200 \mu \mathrm{m}$. B, Colocalization of $\beta$-gal with excitatory neuron marker Camkii. Sections were stained with antibodies against $\beta$-gal and Camkii. Bottom, Enlarged images of areas in dotted square. Arrow indicates f1, Camkii ${ }^{+} \beta$-gal ${ }^{+}$. Arrowhead indicates f2, Camkii $^{+}$only. Empty arrowhead indicates f3, Camkii ${ }^{+}$cells with $\beta$-gal dots. Scale bars: Top, $120 \mu \mathrm{m}$; Bottom, $20 \mu \mathrm{m}$. C, Fewer interneurons were labeled by $\beta$-gal. Brain sections of Neogenin-Lacz;GAD67-GFP mice were stained with antibodies against $\beta$-gal and NeuN. Bottom, Enlarged images of areas in dotted square. Arrow indicates f1, GFP ${ }^{+} \beta$-gal ${ }^{+}$. Arrowhead indicates f2, GFP ${ }^{+}$only. Scale bars: Top, $120 \mu \mathrm{m}$; Bottom, $20 \mu \mathrm{m}$. D, Quantitative analysis of data in $\boldsymbol{B}, \boldsymbol{C}$. Only cells whose entire soma were labeled by Camkii or GFP were scored. $n=8$ slices from 3 mice.

tified. Spines with heads larger than averaged width $(0.75 \mu \mathrm{m})$ were considered mushroom spines; those less than averaged width were considered as thin spines. Filopodia were protrusions $>1.5 \mu \mathrm{m}$ in length without a neck. Branched spines were identified by having two branches from a single spine. The investigator who performed spine analysis was blinded to genotypes.

Virus injection. Virus injection was performed as described previously with minor modification (Lu et al., 2014). In brief, male mice (7-8 weeks old) were anesthetized with ketamine/xylazine (Sigma-Aldrich, 100/20 $\mathrm{mg} / \mathrm{kg}$, respectively, i.p.) and head-fixed in a stereotaxic device (David Kopf Instruments) on a heating pad. An incision was made in the scalp and two small holes, one on each side, were drilled into the skull (BLA coordinates: anteroposterior, -1.5 ; dorsoventral, -4.8 ; mediolateral, \pm 3.2 relative to bregma). The $0.1 \mu \mathrm{l}$ of adeno-associated virus (AAV)Cre-GFP virus (Serotype 5, UNC Vector Core) with titer of $5 \times 10^{12}$ were delivered at $50 \mathrm{nl} / \mathrm{min}$ into each side through a 33-gauge blunt needle and a $5 \mathrm{ml}$ syringe (Hamilton), controlled by an injection pump (World Precision Instruments, System UMP3 with micro4). Ten minutes after injection, needle was slowly retracted. Mice will not be used for subsequent experiments until 3 weeks later.

Behavioral analysis. Mice were handled by investigators for $3 \mathrm{~d}$ before any behavioral test. Locomotor activity was measured as described previously (Sun et al., 2016). Mice were placed in a chamber $(50 \times 50 \times 10$ $\mathrm{cm}$ ), and movement was monitored for $30 \mathrm{~min}$ using an overhead camera and tracking software (EthoVision, Noldus). The center $25 \times 25 \mathrm{~cm}$ region was artificially defined as the center region and duration spent in the center region was recorded.

In the elevated plus maze (EPM) test, each mouse was initially placed in one of the closed arms of plus maze that has two opposing wall-closed arms and two open arms, each at $5 \times 66 \mathrm{~cm}$. The EPM was placed $\sim 50$ $\mathrm{cm}$ above the floor.
Mice movement was recorded for 15 min using an overhead camera and tracking software (EthoVision, Noldus). The time mice spent in the open arms, the number of entries were quantified autonomously.

Tone-cued fear conditioning was conducted in sound-attenuating chambers on metal grid floors that were connected to a shock generator to generate footshock (Coulbourn Instruments). After adaptation for $3 \mathrm{~d}$ ( 5 min per day) in Context A (metal grid floor, interior white light, fans, and mild alcohol scent), mice were subjected to 3 fear conditioning pairings of $30 \mathrm{~s} \mathrm{CS}$ (tone at $80 \mathrm{~dB}, 5000 \mathrm{~Hz}$ ) and footshock (US, $2 \mathrm{~s}, 0.5 \mathrm{~mA}$ ) at the end of CS, with an interval time of $90 \mathrm{~s}$ between each CS-US pairing. One day after pairing, freezing test was conducted by placing mice in a chamber with altered environment (Context B: covered metal grid floor, red light, and $4 \%$ acetic acid scent) for 2 min without CS and 3 min with CS. Chambers were cleaned with 70\% ethanol before each use. Mouse freezing was monitored by an infrared camera and analyzed by Freezeframe 4 software (Coulbourn Instruments) according to the manufacturer's instructions. The freezing threshold for each mouse was set to the value of the trough by examining the motion index histogram. Bout length, which reflects the duration that a single freezing episode must equal or exceed to be counted, was set as $1 \mathrm{~s}$. Freezing rates were calculated autonomously by Freezeframe 4 software. Genotypes of mice in all behavior tests were blinded to investigators.

Experimental design and statistical analysis. Adult male mice $(\geq 2$ month) were used in the study. Animal or replicate numbers for each experiment are listed in figure legends. Statistical analysis was done by the Prism version 5.0 (GraphPad Software). Results of the statistical analyses, including degrees of freedom and exact $p$ values, are presented in figure legends in Results. Sample size choice was based on previous studies (Lu et al., 2014; Sun et al., 2016), not predetermined by a statistical method. No randomization method was used. Data distribution was assumed to be normal, but this was not formally 
A

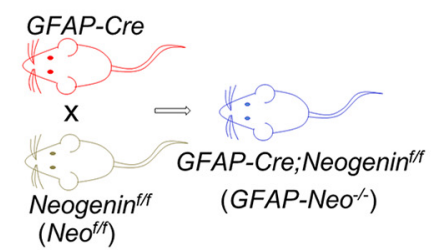

D

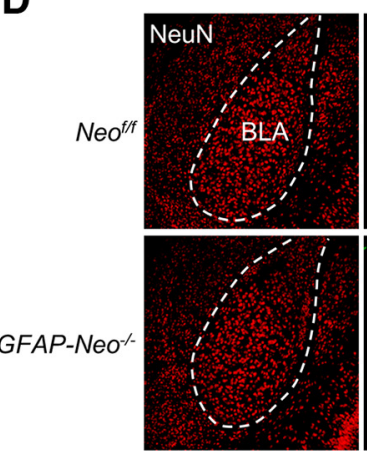

E

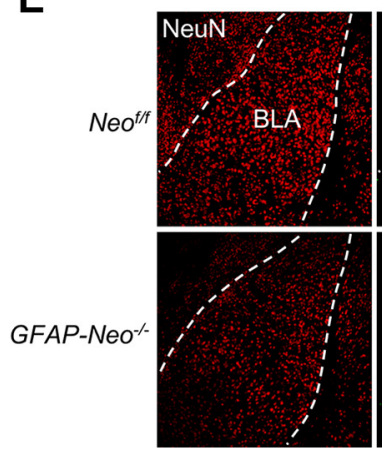

B

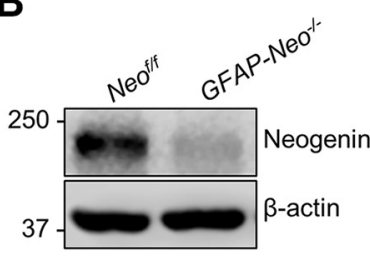

Rostral

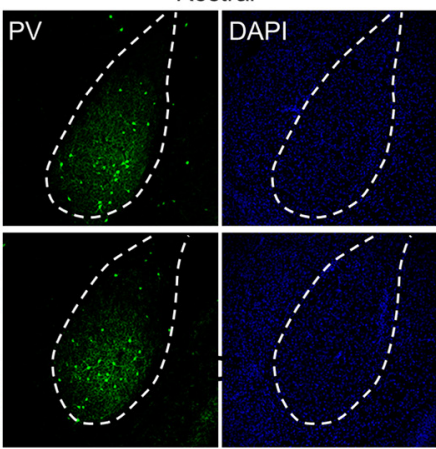

Caudal
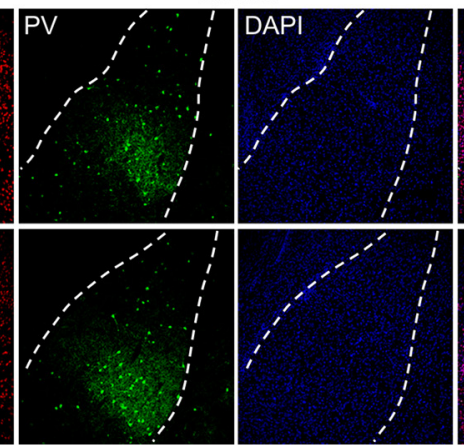
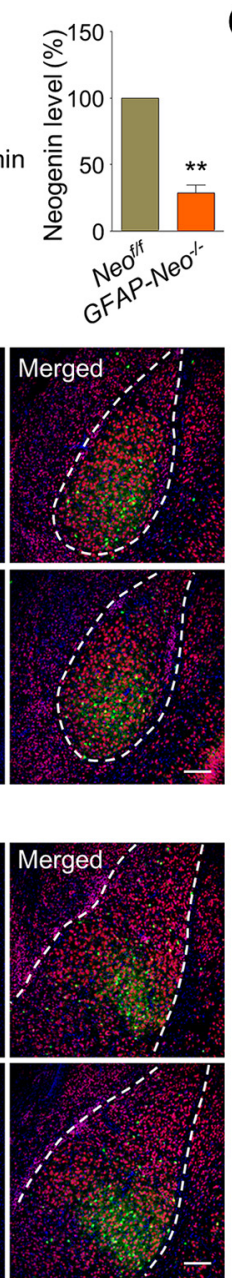

C

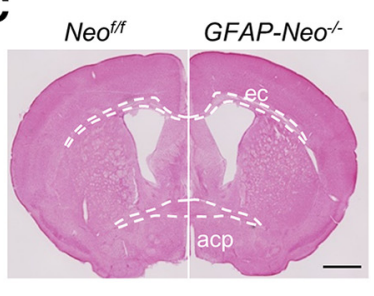

F

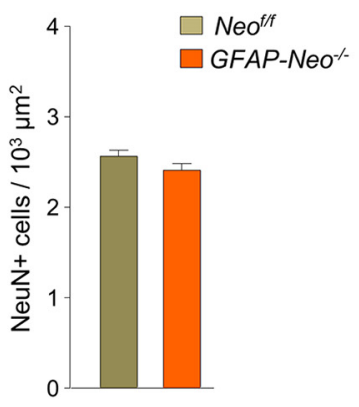

G

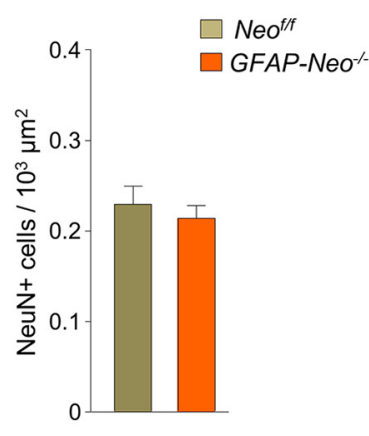

Figure 2. Morphological characterization of GFAP-Neo ${ }^{-1-}$ amygdala. A, Breeding diagram: Neogenin ${ }^{f / f}\left(\mathrm{Neo}^{f / f}\right)$ mice were crossed with GFAP-Cre mice to generate GFAP-Cre;Neogenin ${ }^{f / f}$ $\left(\right.$ GFAP-NeO $\left.^{-1-}\right)$ mice. B, Neogenin expression was dramatically decreased in amygdala of GFAP-Neo ${ }^{-1-}$ mice. $\beta$-actin serves as loading control. Left, Representative blots. Right, Quantitative data. $n=3$ pairs of Neo $0^{f / f}$ and GFAP-NeO ${ }^{-1-}$ mice. Paired Student's t test: ${ }^{* *} p<0.01$. C, Similar axon projections in Neogenin mutant brain. acp, Posterior part of anterior commissure; ec, external capsule Scale bar, $1 \mathrm{~mm}$. D, Rostral sections of Neo ${ }^{\text {f/f }}$ (top) and GFAP-Neo ${ }^{-/-}$(bottom) amygdala were stained for neuron marker NeuN and interneuron marker PV. Scale bar, $100 \mu \mathrm{m}$. E, Caudal sections of Neo ${ }^{f / f}$ (top) and GFAP-Neo ${ }^{-1-}$ (bottom) amygdala were stained for neuron marker NeuN and interneuron marker PV. Scale bar, $100 \mu \mathrm{m}$. F, Quantification of NeuN ${ }^{+}$cells in the BLA regions. $n=$ 13 slices from $3 \mathrm{Neo}^{f / f}$ mice; $n=17$ slices from 3 GFAP-Neo ${ }^{-1-}$ mice. Student's test: $p>0.05$. G, Quantification of PV ${ }^{+}$cells in the BLA regions. $n=13$ slices from $3 \mathrm{Neo}^{f / f}$ mice; $n=17$ slices from 3 GFAP-Neo $^{-1-}$ mice. Student's $t$ test: $p>0.05$.

tested. Two-way ANOVA was used in morphological and electrophysiological studies that analyze more than two parameters. Student's $t$ test or paired Student's $t$ test was used to compare data from two groups. All tests were two-sided. Error bars indicate SEM. $p<$ 0.05 was considered to be statistically significant.

\section{Results}

\section{Enriched expression of Neogenin in excitatory neurons} in BLA

Neogenin was detected in the brain (van den Heuvel et al., 2013; Huang et al., 2016); however, its exact expression pattern in adult brain is not clear due to the lack of reliable antibodies for immunohistochemical study (data not shown). To this end, we used Neogenin-lacZ mice where the LacZ gene was inserted in the intron of the Neogenin gene (Lee et al., 2010). Under the control of the endogenous promoter, $\beta$-gal expression is thought to faithfully indicate where Neogenin is expressed (Huang et al., 2016). In light of its role in neural development, $\beta$-gal expression of Neogenin-lacZ heterozygous mice was characterized to avoid the potential effect of Neogenin deletion on morphology. Heterozygous mutation had no apparent effect on global morphology of brain structures (data not shown). As shown in Figure $1 A, \beta$-gal activity was high in the BLA, ventral posteromedial/posterolateral thalamic nucleus (VPM/VPL), and subgranular zone (SGZ) of the DG, but weak in CeA, consistent with a previous report (Sun et al., 2018). These results could suggest that Neogenin is enriched in BLA. In support of this notion are in situ images of Neogenin mRNA distribution from the Allen Brain Atlas (http://mouse.brain-map. org/experiment/show? id=68843817; http://mouse.brain-map. org/experiment/show?id=70813035). To identify which type of neurons expresses Neogenin, we performed immunofluorescent costaining on amygdala slices. Most $\beta$-gal-labeled cells were positive for neuronal marker NeuN and excitatory neuron marker Camkii, with percentage of $\sim 95 \%$ and $85 \%$, respectively. Approximately $5 \%$ of $\beta$-gal ${ }^{+}$cells were GAD67-positive interneurons (Fig. $1 B-D$ ). These results indicate that Neogenin expresses mostly in excitatory neurons in BLA.

\section{Impaired fear memory in Neogenin mutant mice}

To investigate the role of Neogenin in the brain, we generated brain-specific Neogenin mutant mice by crossing Neogenin- 
A

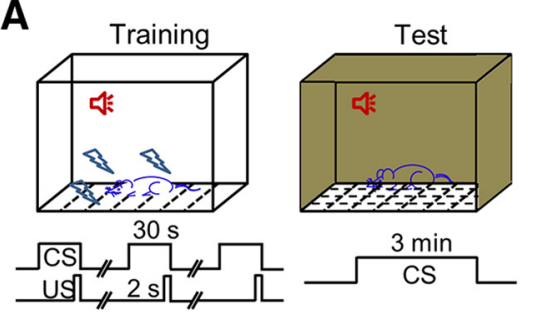

C
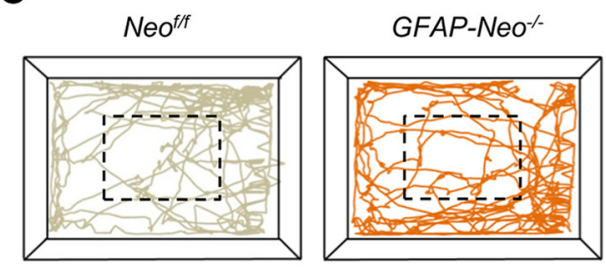

F

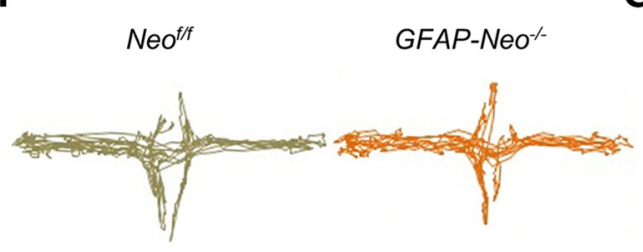

B

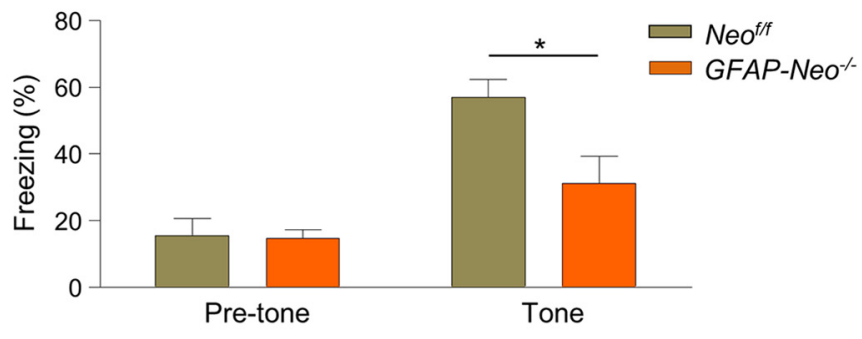

D

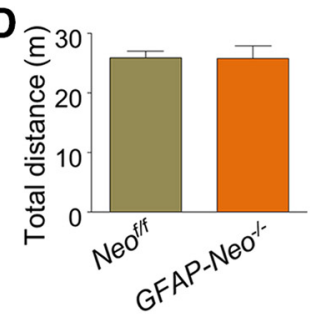

E

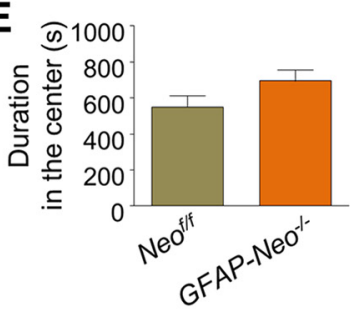

G

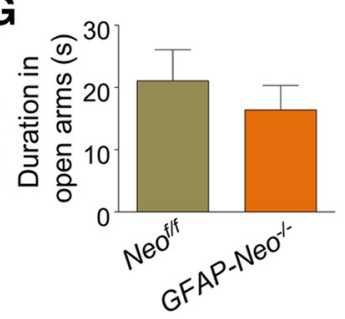

H

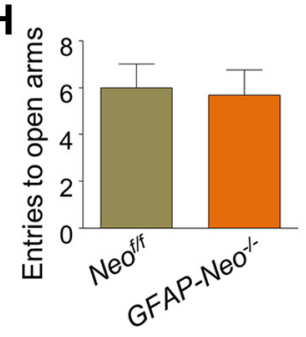

Figure 3. Fear memory deficitin Neogenin mutant mice. $A$, Diagram of tone-cued fear conditioning. Footshocks were delivered 3 times (US, $0.5 \mathrm{~mA}, 2 \mathrm{~s}$ ) at the end of CS (tone, $30 \mathrm{~s}$ ) during training. One day later, freezing test was conducted by placing mice in a chamber with altered environment for 3 min with CS. B, Reduced freezing time in the presence of tone in GFAP-Neo ${ }^{-1-}$ mice. $n=$ 12 mice for each genotype. Student's $t$ test, for pretone group: $p>0.05$; for tone group: ${ }^{*} p<0.05$. C, Representative traces of first 5 min in the open field test. $\boldsymbol{D}, \boldsymbol{E}$, Similar travel distance $(\boldsymbol{D})$ and duration spent in the center $(\boldsymbol{E})$ of mutant mice in $30 \mathrm{~min} . n=12$ mice for each genotype. Student's $t$ test: $p>0.05$. $\boldsymbol{F}$, Representative traces of EPM test. $\boldsymbol{G}, \boldsymbol{H}$, No difference in duration in the open $\operatorname{arms}(\boldsymbol{G})$ and number of entries to open arms $(\boldsymbol{H}) . n=12$ mice for each genotype. Student's $t$ test: $p>0.05$.

floxed (Neo ${ }^{f / f}$ ) mice (Huang et al., 2016) with GFAP-Cre mice where Cre expression is under control of the human GFAP promoter. In GFAP-Cre mice, Cre expression is restricted in neural progenitor cells that give rise to neurons and glial cells in the brain (Zhuo et al., 2001) (Fig. 2A). Resulting GFAP-Cre;Neogenin ${ }^{f / f}$ (hereafter referred as GFAP-Neo ${ }^{-/}$) mice showed little Neogenin expression in lysates of amygdala (Fig. $2 B$; paired Student's $t$ test, $t_{(2)}=$ $12.18, p=0.0067$ ), indicating Neogenin deletion. GFAP-Neo ${ }^{-1-}$ mice were viable and showed no difference in body weight, compared with their littermates-Neo f/f mice (data not shown). Neogenin is a receptor for Netrin-1 and RGM (De Vries and Cooper, 2008); this pathway has been implicated in projections of commissural axons in the spinal cord (Serafini et al., 1996; Matsumoto et al., 2007). We examined axonal projections in the brain of GFAP-Neo ${ }^{-1-}$ mice by measuring external capsule (ec), which connects two hemispheres and posterior part of anterior commissure (acp), which links the bilateral amygdalae. As shown in Figure $2 C$, the length and area of ec and acp in GFAP-Neo ${ }^{-1-}$ mice were comparable with those in $\mathrm{Neo}^{\mathrm{f} / f}$ mice. This result suggests that Neogenin may not be necessary for axonal projections of external capsules and anterior commissures. In addition, neither NeuN-positive neuron density nor PV-positive interneuron density in rostral and caudal sections of BLA was changed in GFAP-Neo ${ }^{-1-}$ mice (Fig. 2D-G; for NeuN Fig. 2F, Student's $t$ test, $t_{(28)}=1.557, p=0.1306$; for PV Fig. $2 G$, Student's $t$ test, $\left.t_{(28)}=0.6618, p=0.5135\right)$, suggesting that Neogenin may be dispensable in neuronal proliferation and migration in BLA.

In light of the critical role of amygdala in emotion and emotion-related memory processing and abundant expression of
Neogenin in BLA, we hypothesized that Neogenin may regulate functions of amygdala. To test this hypothesis, mice were subjected to the tone-cued fear conditioning (TFC) test, a classic behavioral paradigm for amygdala function (Maren, 2001) (Fig. $3 A$ ). After 3 pairs of tone and footshock during the training day, freezing levels of mice were examined in a new environment on the test day. GFAP-Neo ${ }^{-1-}$ mice showed similar freezing level before tone presence. However, freezing time was decreased in GFAP-Neo ${ }^{-1-}$ mice in response to tone, compared with $\mathrm{Neo}{ }^{f / f}$ mice (Fig. $3 B$; for pretone group, Student's $t$ test, $t_{(22)}=0.1415$, $p=0.8888$; for tone group, Student's $t$ test, $t_{(22)}=2.649, p=$ $0.0146)$. These results suggest impaired fear memory in Neogenin mutant mice. To determine whether this effect is specific, we tested GFAP-Neo ${ }^{-1-}$ mice in the open-field and EPM. In the open-field test, GFAP-Neo ${ }^{-1-}$ mice exhibited similar travel distance in 30 min compared with $\mathrm{Neo}^{f / f}$ mice (Fig. $3 \mathrm{C}, \mathrm{D}$; Student's $t$ test, $t_{(22)}=0.0223, p=0.982$ ), suggesting unaltered locomotor activity in Neogenin mutant mice. In addition, the duration that GFAP-Neo ${ }^{-1-}$ mice spent in the center is comparable with their littermate $N e o^{f / f}$ mice (Fig. 3E; Student's $t$ test, $t_{(22)}=1.732, p=$ 0.0973), implicating that the anxiety level may not be affected by Neogenin mutation. In EPM test, the duration that Neogenin mutant mice spent in the open arm and the number of entries to open arms were both similar to that of $\mathrm{Neo}^{f / f}$ mice (Fig. $3 \mathrm{~F}-\mathrm{H}$; for Fig. $3 G$, Student's $t$ test, $t_{(22)}=0.7451, p=0.4641$; for Fig. $3 H$, Student's $t$ test, $\left.t_{(22)}=0.2254, p=0.8237\right)$, indicating their normal anxiety level, in agreement with data from OFT. Together, these results indicate that Neogenin deletion specifically impairs fear memory. 
A
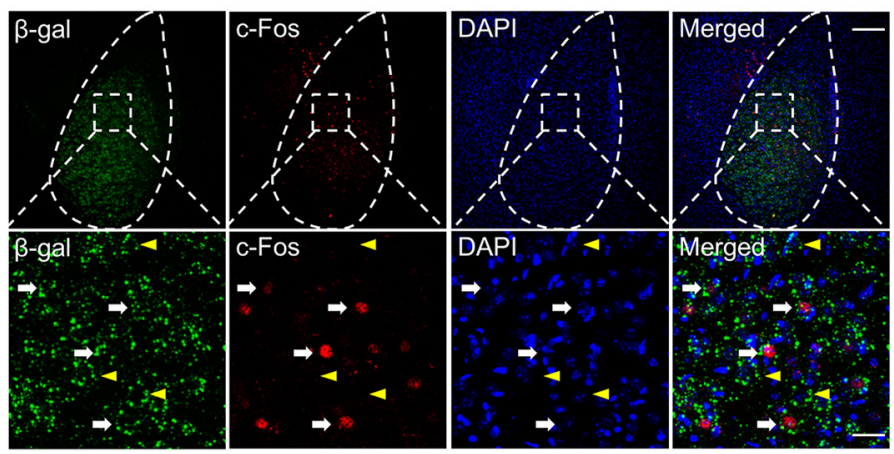

C
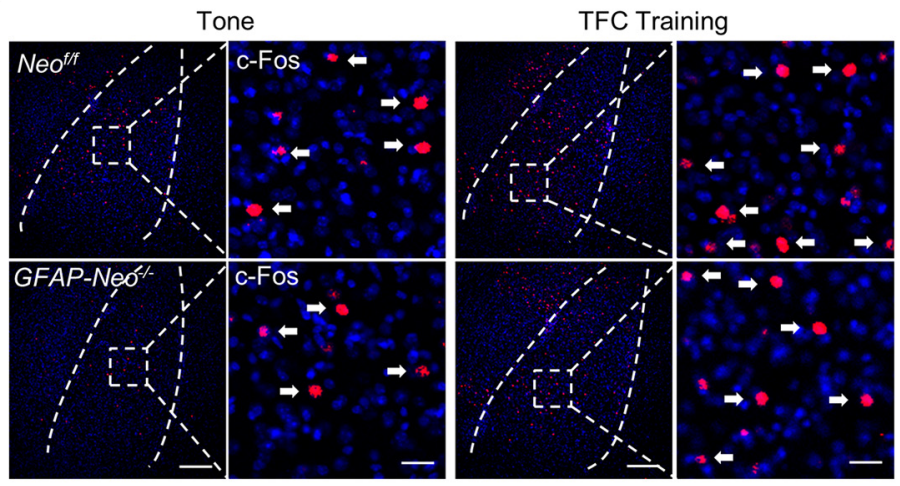

B

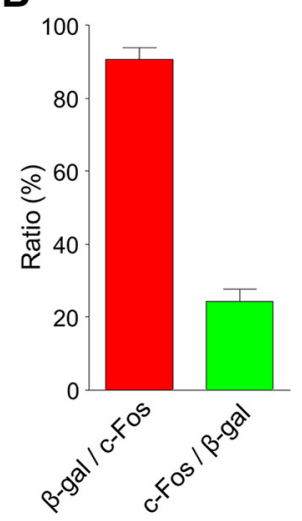

D

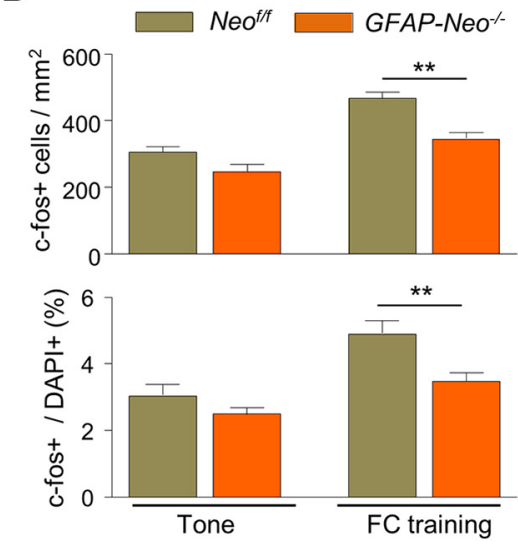

Figure 4. Impaired neuronal activation in the BLA of Neogenin knock-out mice. $\boldsymbol{A}$, Colocalization of $\beta$-gal with neuronal activation marker c-Fos. Neogenin-Lacz heterozygous mice were subject to fear conditioning (FC) training. At $1.5 \mathrm{~h}$ later, brains were collected and cut into coronal slices. Sections were stained with antibodies against $\beta$-gal and c-Fos. Bottom, Enlarged images of areas in dotted square. Arrows indicate cells positive for $\beta$-gal and c-Fos. Arrowheads indicate cells positive for $\beta$-gal, but not c-Fos. Scale bars: Top, $120 \mu \mathrm{m}$; Bottom, $20 \mu \mathrm{m}$. B, Quantitative analysis of data in $\boldsymbol{A}$. A total of $90.7 \%$ of c-Fos ${ }^{+}$cells were $\beta$-gal positive, whereas $24.3 \%$ of $\beta$-gal positive cells were c-Fos ${ }^{+} . n=7$ slices from 3 Neo ${ }^{f / f}$ mice. $\boldsymbol{C}, c_{-F}$ os expression in Neo ${ }^{f / f}$ and $G F A P-N e o^{-1-}$ amygdala in response to tone and TFC. At $1.5 \mathrm{~h}$ after tone presence or TFC, mouse brains were fixed for immunostaining with c-Fos antibodies. Right, Enlarged images of areas in dotted square. Arrows indicate cells positive for c-Fos. Scale bars: Left, $100 \mu \mathrm{m}$; Right, $20 \mu \mathrm{m}$. D, Quantitative analysis of data in $C . n=9$ slices from 3 mice for each group. Student's $t$ test: $p>0.05$ for CS; ${ }^{* *} p<$ 0.01 for TFC.

\section{Aberrant neuronal activation in the BLA of Neogenin mutant mice}

The impairment of fear memory could be due to damaged neuronal activation in the amygdala in Neogenin mutant mice upon behavioral stimulation (Huang et al., 2014). To examine this possibility, we characterized cFos ${ }^{+}$cells in the BLA following TFC training. We first tested whether Neogenin colocalizes with cFos in the BLA following TFC by costaining $\beta$-gal and cFos antibodies on amygdala sections from Neogenin-lac Z heterozygous mice. As shown in Figure $4 A$, the majority of $\mathrm{cFos}^{+}$cells are $\beta$-gal-positive $(90.7 \%)$, although a minor portion of $\beta$-gal-positive cells were $\mathrm{cFos}^{+}(24.3 \%)$ (Fig. $4 B$ ), suggesting that a subtype of Neogeninpositive cells, most probably excitatory neurons, mediates the fear memory processing.

When $\mathrm{Neo}^{\text {flf }}$ and GFAP-Neo ${ }^{-/-}$mice were subjected to tone alone (i.e., not paired with footshock), $\mathrm{CFos}^{+}$cells were similar between the two genotypes $\left(308 \pm 23.2 / \mathrm{mm}^{2}\right.$ for $\mathrm{Neo}^{\mathrm{f} / f}$ mice and $247.2 \pm 21.8 / \mathrm{mm}^{2}$ for GFAP-Neo ${ }^{-1-}$ mice. Although there was a trend of reduction in mutant mice, the reduction was not statistically different ( $p=0.0731$, Student's $t$ test, $\left.t_{(16)}=1.918\right)$. Although TFC training increased $\mathrm{cFos}^{+}$cells in both genotypes, the increase was significantly smaller in mutant than that of control mice $\left(467.8 \pm 17.2 / \mathrm{mm}^{2}\right.$ and $347.2 \pm 22.3 / \mathrm{mm}^{2}$ for $\mathrm{Neo} / f$ and GFAP-Neo ${ }^{-1-}$ mice, respectively; Student's $t$ test, $t_{(16)}=4.28$, $p=0.0006)$. Similar results were obtained when $\mathrm{cFos}^{+}$cells/ $\mathrm{DAPI}^{+}$cells were analyzed in mice that were subjected to only tone $\left(2.95 \pm 0.24\right.$ and $2.43 \pm 0.14$ for $N e o^{f / f}$ and GFAP-Neo ${ }^{-/-}$ mice, respectively; Student's $t$ test, $t_{(16)}=1.881, p=0.0783$ ). Upon TFC training, the numbers were increased to $4.77 \pm 0.30$ and $3.39 \pm 0.21$, respectively (Student's $t$ test, $t_{(16)}=3.775, p=$ $0.0017)$. These results indicate aberrant neuronal activation in Neogenin mutant mice.

Compromised excitatory synaptic transmission and plasticity in the BLA of Neogenin mutant mice

Reduced neuronal activation upon behavioral stimulation could be caused by decreased intrinsic excitability of neurons, increased inhibitory synaptic activity, or depressed excitatory synaptic activity. To investigate the cellular mechanisms for reduced neuronal activation in GFAP-Neo ${ }^{-1-}$ mice, we first examined neuronal intrinsic property in whole-cell configuration (Fig. 5A). Resting membrane potential and input resistance of pyramidal neurons in the BLA of GFAP-Neo ${ }^{-1-}$ mice were comparable with those of $N e o^{f / f}$ mice (Fig. $5 B, C$; for Fig. $5 B$, Student's $t$ test, $t_{(22)}=0.7545$, $p=0.4586$; for Fig. $5 C$, Student's $t$ test, $t_{(22)}=0.0785, p=$ $0.9381)$. In addition, the firing rates in response to current injections at gradually increased intensity were not altered (Fig. $5 D$; two-way ANOVA, $\left.F_{(1,112)}=0.4788, p=0.4904\right)$. These results 
A

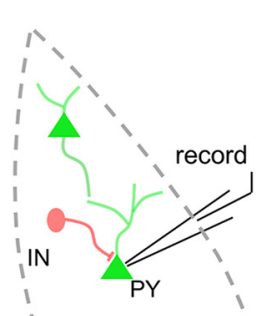

B

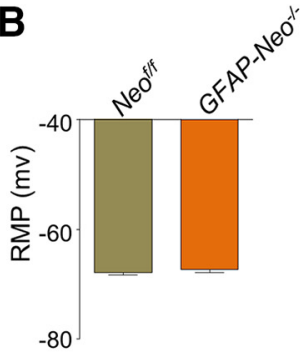

E

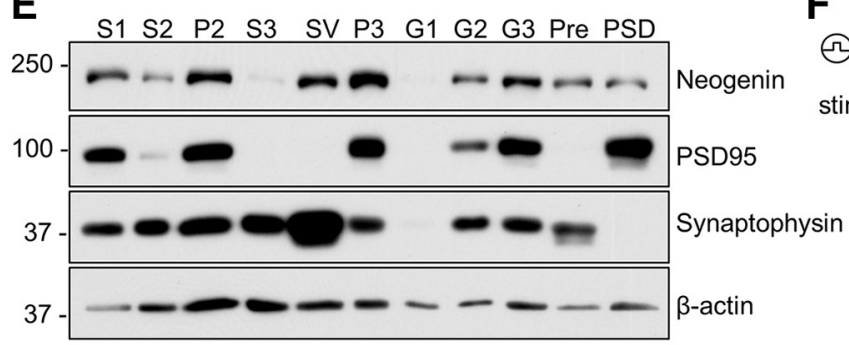

C

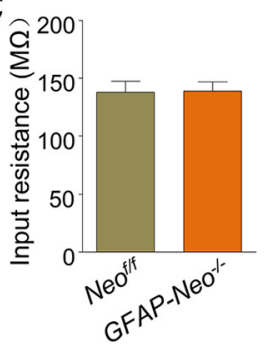

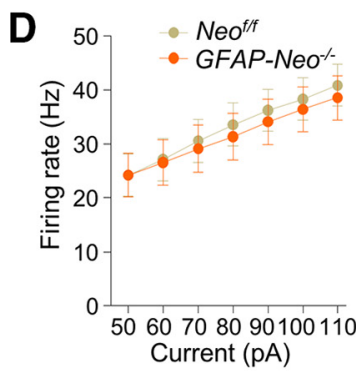

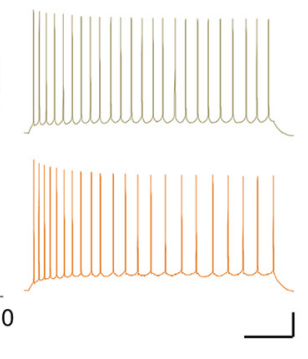

Current (pA)
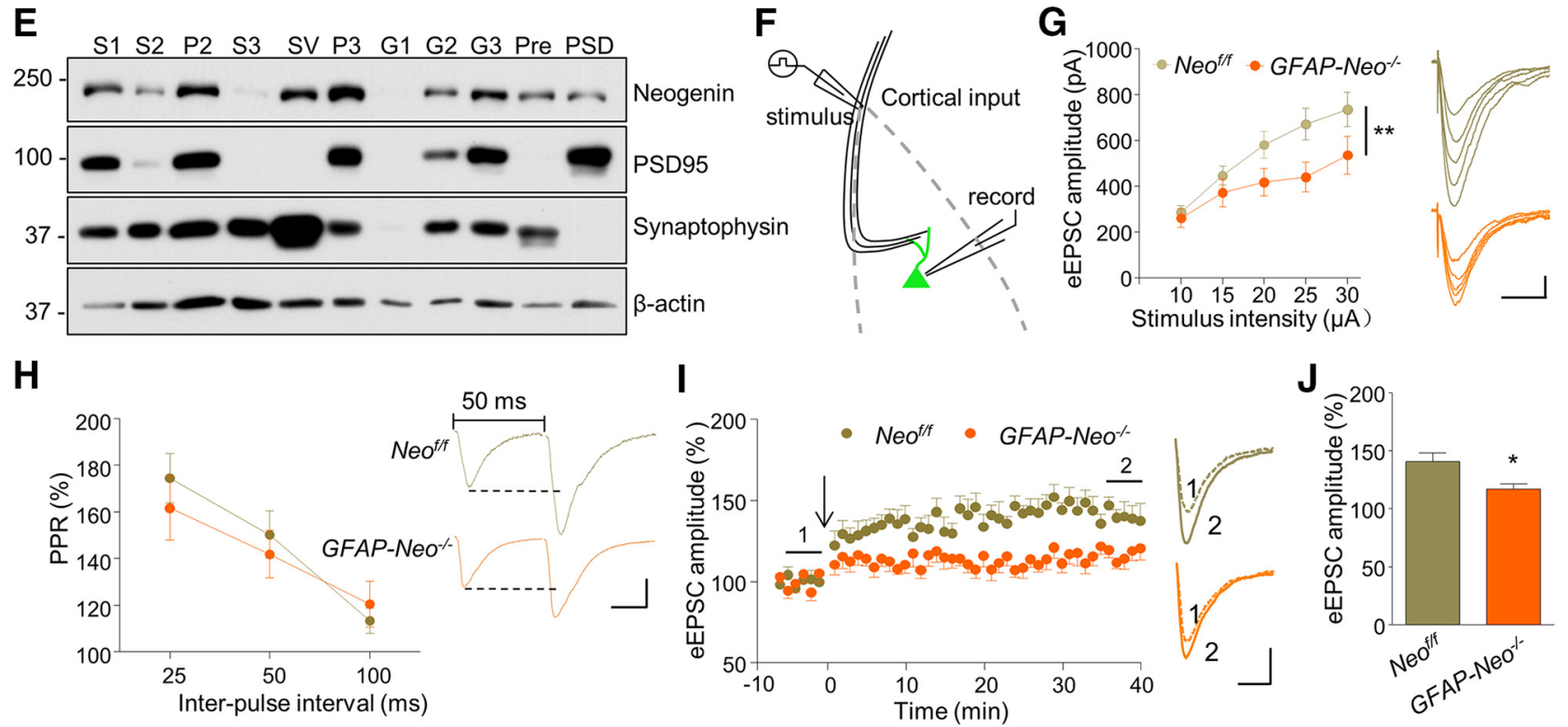

Figure 5. Compromised excitatory synaptic transmission and synaptic plasticity in the BLA of Neogenin knock-out mice. $\boldsymbol{A}$, Recording diagrams. Pyramidal neurons in the BLA were recorded in whole-cell configuration. $B$, Similar resting membrane potential (RMP) of pyramidal neurons in GFAP-Neo ${ }^{-1-}$ amygdalae. $n=12$ neurons from 3 mice for each genotype. Student's $t$ test: $p>0.05$. C, Unaltered membrane input resistance (Rin) of pyramidal neurons in GFAP-Neo ${ }^{-/-}$amygdala. $n=12$ neurons from 3 mice for each genotype. Student's $t$ test: $p>0.05$. $D$, Firing rate plotted against increasing injected currents. $n=9$ neurons from 3 mice for each genotype. Two-way ANOVA: $F_{(1,112)}=0.4788, p>0.05$. Right, Representative traces of spikes in BLA pyramidal neurons evoked by injecting depolarizing currents of 50 pA. Scale bars, $200 \mathrm{~ms}, 20 \mathrm{mV}$. E, Subcellular fractions of amygdala were probed for Neogenin, the postsynaptic marker PSD95, the presynaptic marker synaptophysin, and $\beta$-actin (loading control). S1, Supernatant 1; S2, supernatant 2; P2, crude synaptosome-enriched pellet; S3, crude synaptic vesicle fraction; SV, synaptic vesicle fraction; P3, synaptosomal membrane fraction; G1, myelin fraction; $G 2$, light membrane fraction; G3, synaptosomal plasma membrane fraction; Pre, presynaptic fraction; PSD, postsynaptic density fraction. $F$, Recording diagram. Pyramidal neurons in the BLA were recorded in whole-cell configuration. Cortical input pathway was stimulated. G, Downward shifted I/0 curve in GFAP-Neo ${ }^{-/-}$slice. eEPSCS were recorded in BLA pyramidal neurons in response to stimulation of the cortical pathway with increasing intensities. $n=9$ neurons from 3 mice for each genotype. Tw0-way ANOVA: ${ }^{* *} p<0.01$. Right, Representative eEPSC traces. Scale bars, $20 \mathrm{~ms}, 150$ PA. $\boldsymbol{H}$, PPRs plotted against interstimulus intervals. $n=12$ neurons from 3 Neo ${ }^{\mathrm{f} / f}$ mice; $n=13$ neurons from 3 GFAP-Neo ${ }^{-1-}$ mice. Two-way ANOVA: $p>0.05$. Right, Representatives sweeps with interstimulus interval of pair-pulse stimulations at $50 \mathrm{~ms}$. Scale bars, $20 \mathrm{~ms}, 50$ pA. $I$, Suppressed LTP expression in GFAP-Neo ${ }^{-/-}$ BLA. Whole-cell LTP was recorded in BLA excitatory neurons in response to stimulation of the cortical pathway. Arrow indicates the time of $L T P$ induction. Representative eEPSC traces of pre (1) and post (2) induction. Scale bars, 20 ms, 50 pA. J, Quantitative analysis of data in I. $n=7$ neurons from 3 Neo ${ }^{f / f}$ mice; $n=9$ neurons from GFAP-Neo ${ }^{-/-}$mice. Student's $t$ test: ${ }^{*} p<0.05$.

suggest that the intrinsic excitability of pyramidal neurons is not influenced by Neogenin mutation.

By isolating subcellular fractions, we have found that Neogenin was located in both presynaptic and postsynaptic fractions (Fig. $5 E$ ), suggesting a possible role of Neogenin in synaptic transmission. To determine whether Neogenin mutation alters neurotransmission at afferent inputs to the BLA, we characterized eEPSCs in response to stimuli with increasing intensities to cortical afferent pathway (Fig. $5 F$ ). As shown in revised Figure $5 G$, the input/output (I/O) curve was shifted downward in Neogenin mutant mice, compared with control. This suggests a compromised afferent input to BLA pyramidal neurons in GFAP-Neo ${ }^{-1-}$ BLA (two-way ANOVA, $F_{(1,64)}=13.2, p=0.0006$ ). To determine whether this is due to a problem in presynaptic glutamate release, we characterized PPRs of eEPSCs in BLA pyramidal neurons in response to two consecutive stimulations. PPRs in GFAP-Neo ${ }^{-1-}$ slices were similar to that in $\mathrm{Neo}^{f / f}$ slices (Fig. $5 \mathrm{H}$, two-way ANOVA, $\left.F_{(1,69)}=0.3039, p=0.5832\right)$, suggesting normal glutamate release probability in $G F A P-N e o^{-1-}$ mice. We next asked whether Neogenin was required for synaptic plasticity in the BLA by recording LTP of BLA pyramidal neurons in wholecell configuration. eEPSCs were evoked in BLA excitatory neurons by using a pairing protocol where 100 stimuli at $2 \mathrm{~Hz}$ were delivered to cortical afferents with postsynaptic membrane potential holding at $30 \mathrm{mV}$ (Liu et al., 2017). Both induction and maintenance of LTP were compromised in GFAP-Neo ${ }^{-1-}$ slices (Fig. 5I,J; Student's $t$ test, $t_{(14)}=2.859, p=0.0134$ ), revealing a role of Neogenin in synaptic plasticity.

\section{Reduced mEPSC frequency and spine density in GFAP-Neo ${ }^{-1-}$ BLA}

To investigate underlying mechanisms of impaired synaptic transmission, we recorded mEPSCs of pyramidal neurons in the BLA (Fig. 6A). mEPSC amplitudes were comparable between 

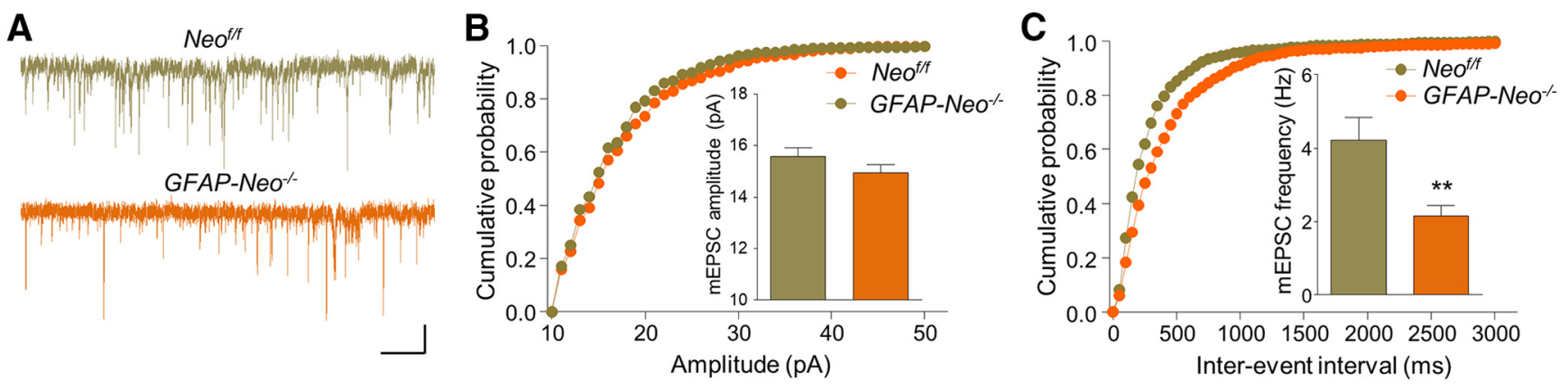
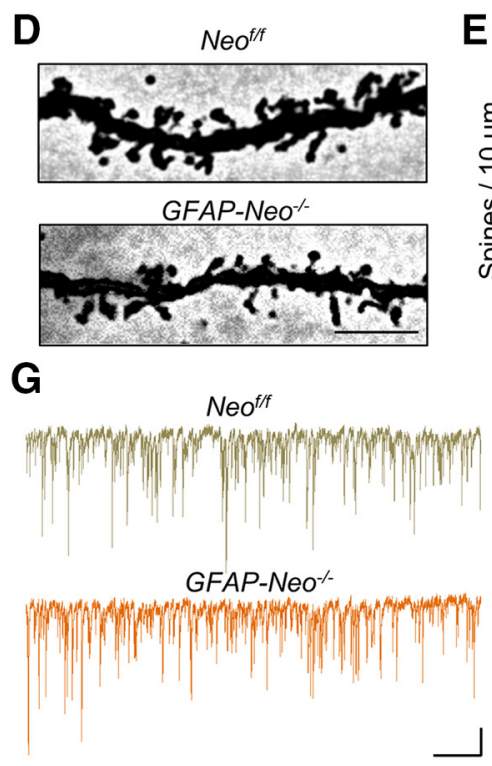
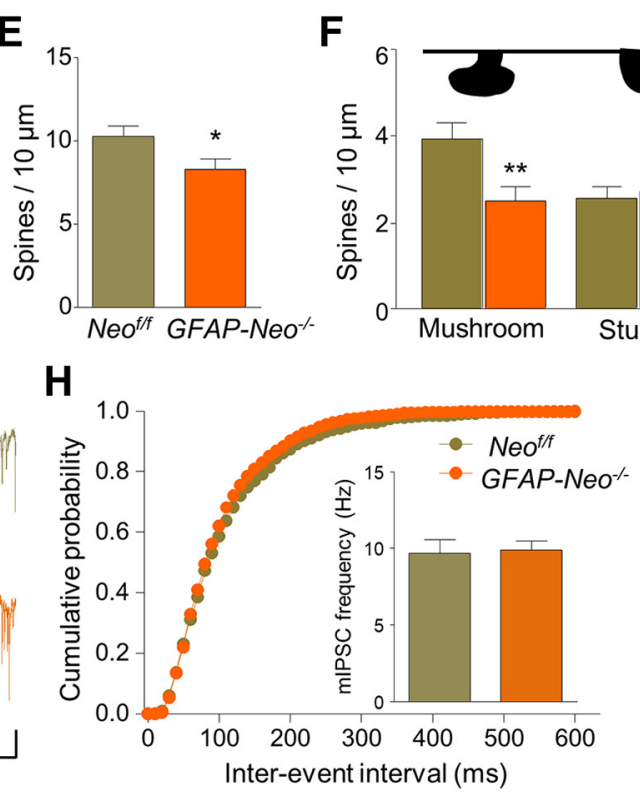

.
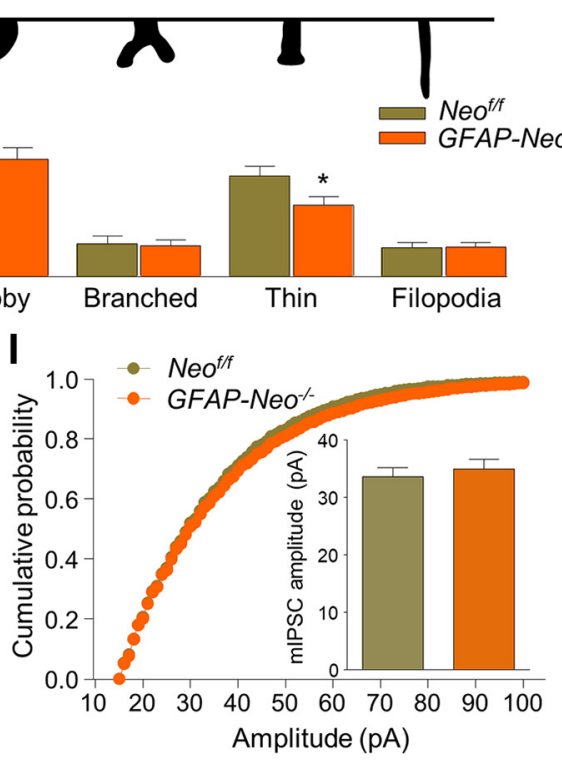

Figure 6. Reduced mEPSC frequency and spine density in the BLA of Neogenin mutant mice. $A$, Representative traces of mEPSCs in BLA pyramidal neurons from Neo ${ }^{f / f}$ and GFAP-Neo ${ }^{-/-}$mice. Scale bars, $2 \mathrm{~s}, 10$ pA. B, Cumulative probability plots and histograms of mEPSC amplitude. $n=18$ neurons from 4 mice for each genotype. Student's $t$ test: $p>0.05$. C, Cumulative probability plots of mEPSC interevent intervals and histograms of mEPSC frequency. $n=18$ neurons from 4 mice for each genotype. Student's $t$ test: ${ }^{* *} p<0.01$. $\boldsymbol{D}$, Representative images in Golgi staining. Scale bars, $5 \mu \mathrm{m}$. $\boldsymbol{E}$, Decreased spine density in BLA pyramidal neurons of GFAP-Neo ${ }^{-/-}$mice. $n=13$ neurons from 3 Neo ${ }^{f / f}$ mice; $n=15$ neurons from 4 GFAP-Neo ${ }^{-/-}$mice. Student'st test: ${ }^{*} p<0.05$. $\boldsymbol{F}$, Decreased densities of mushroom and thin spines in BLA pyramidal neurons of GFAP-Neo ${ }^{-1-}$ mice. $n=13$ neurons from $3 \mathrm{NeO}^{f / f}$ mice and $n=15$ neurons from 4 GFAP-Neo ${ }^{-1-}$ mice. Student's $t$ test: for mushroom, ${ }^{* *} p<0.01$; for thin, ${ }^{*} p<0.05$; for the rest, $p>0.05$. Top, Diagram of spine shape. G, Representative traces of mIPSCs in BLA pyramidal neurons from Neo ${ }^{f / f}$ and $G F A P-N e 0^{-/-}$ mice. Scale bars, $2 \mathrm{~s}, 20 \mathrm{pA}$. $\boldsymbol{H}, \boldsymbol{I}$, Cumulative probability plots of mIPSC interevent intervals and histograms of mIPSC frequency $(\boldsymbol{H})$ and amplitude $(\boldsymbol{I}) . n=16$ neurons from 4 Neo ${ }^{f / f}$ mice; $n=17$ neurons from 4 GFAP-Neo ${ }^{-1-}$ mice. Student's $t$ test: $p>0.05$.

GFAP-Neo ${ }^{-/-}$and Neo $o^{f / f}$ BLAs (Fig. 6B; Student's $t$ test, $t_{(34)}=$ $1.352, p=0.1853)$. However, mEPSC frequency in GFAP$\mathrm{Neo}^{-/-}$BLA was decreased (Fig. 6C; Student's $t$ test, $t_{(34)}=3.054$, $p=0.0044)$. In light of no change in presynaptic release probability (Fig. $5 H$ ), these results suggest a possible reduction in release sites (i.e., synapse number). Indeed, Golgi staining indicated reduced spine numbers in GFAP-Neo ${ }^{-/-}$BLA, compared with control (Fig. $6 D, E$; Student's $t$ test, $t_{(26)}=2.208, p=$ $0.0363)$. In particular, the densities of mushroom and thin spines were reduced by Neogenin mutation (Fig. 6F; Student's $t$ test; for mushroom, $t_{(26)}=2.882, p=0.0078$; for stubby, $t_{(26)}=0.4493$, $p=0.6569$; for branched, $t_{(26)}=0.2648, p=0.7932$; for thin, $t_{(26)}=2.197, p=0.0371$; for filopodia, $t_{(26)}=0.1369, p=$ 0.8922 ). These results suggest an important role of Neogenin in spine development. We also recorded mIPSCs of pyramidal neurons in the BLA (Fig. 6G). Neither frequency nor amplitude was changed by Neogenin mutation (Fig. $6 \mathrm{H}, \mathrm{I}$; Student's $t$ test; for Fig. $6 H, t_{(31)}=0.2095, p=0.8354$; for Fig. $6 I, t_{(31)}=0.5488, p=$ 0.5871 ), indicating normal inhibitory transmission in GFAP$\mathrm{Neo}^{-1-}$ BLA. Together, these observations suggest that Neogenin mutation specifically alters excitatory synaptic transmission in the BLA, revealing an underlying mechanism for reduced neuron activation in Neogenin mutant mice.

\section{Maintenance of excitatory synaptic transmission by Neogenin} in adult mice

Because of embryonic and ubiquitous expression of Cre drived by GFAP promoter, we were unable to exclude the possibility that the defects in GFAP-Neo ${ }^{-1-}$ mice may be attributed to Neogenin loss of function in other regions, including cortex and hippocampus (Huang et al., 2016). To examine whether Neogenin in BLA at adult stage is critical for fear memory, $\mathrm{Neo}^{f / f}$ mice were crossed with Ai9 reporter mice (The Jackson Laboratory, \#007909), which contains a loxp-flanked STOP cassette preventing transcription of a CAG promoter-driven red fluorescent protein variant (tdTomato) $\left(t d^{+}\right)$. When crossed with a Cre line or injected with a Cre virus, tdTomato in $t d^{+}$mice is expressed (Madisen et al., 2010), which enabled easy identification of cells for electrophysiological recording. We bilaterally injected AAV-expressing Cre recombinase (AAV-Cre-GFP) into BLA of adult male $t d^{+}$ and $N e o^{f / f} ; t^{+}$mice (Fig. $7 A, B$ ). Three weeks later, Neogenin level was reduced in the amygdala (Amyg), but not in the hypo- 
A

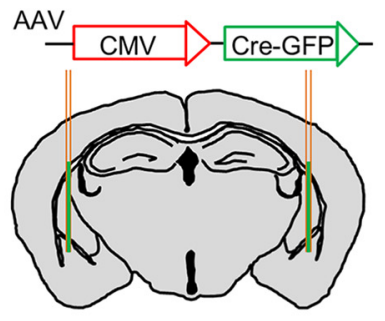

B

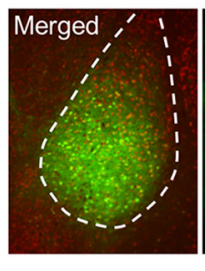

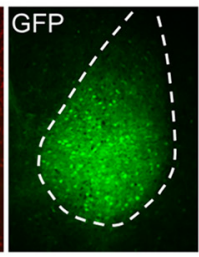

E

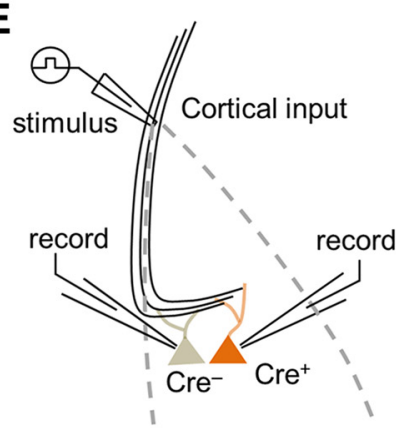

C

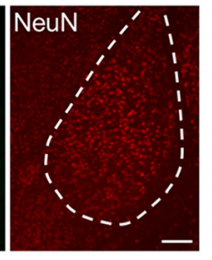

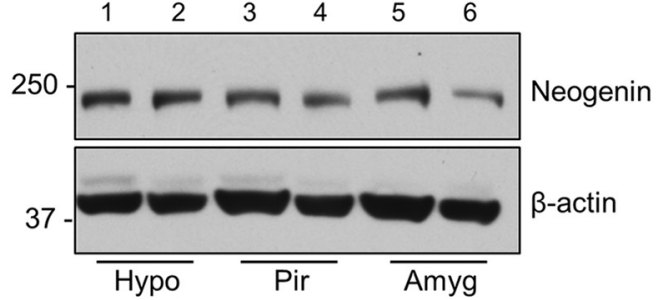

$\mathbf{F}$

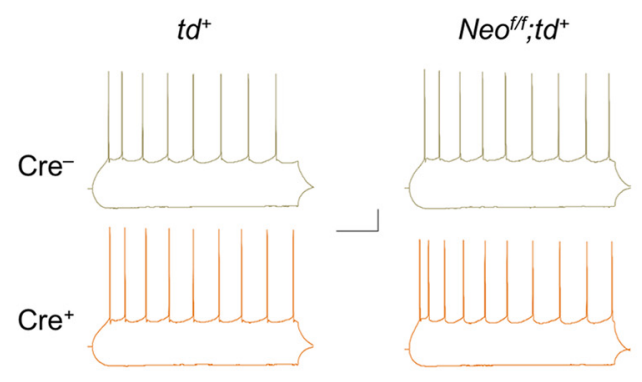

I
G

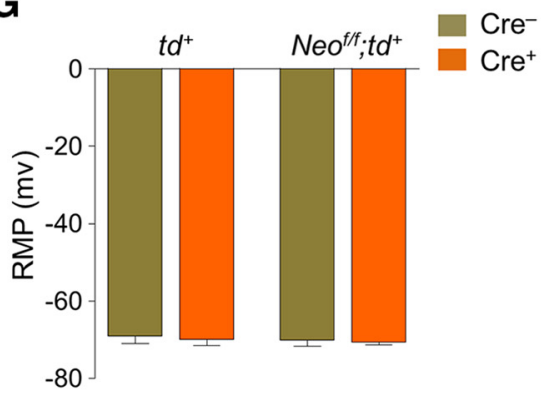

$\mathbf{H}$

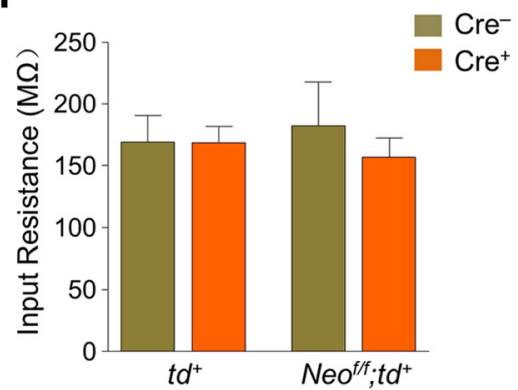

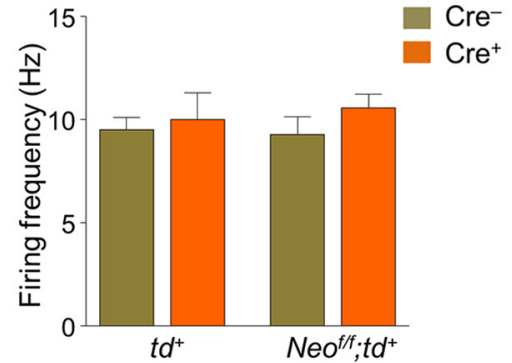

Figure 7. Unaffected neuronal intrinsic property by Cre virus infection and Neogenin mutation. $A, A$ schematic of virus injection. CMV promoter-driven Cre virus was injected bilaterally into BLA region. $\boldsymbol{B}$, Expression of GFP in virus-injected mice. Amygdala sections were stained with GFP and NeuN antibodies 3 weeks after stereotaxic microinjection of AAV-Cre-GFP virus. Scale bar, $100 \mu m$. C, Reduced Neogenin expression in amygdala of $\mathrm{Neo}^{t / f} ; t d^{+}$mice injected with AAV-Cre-GFP virus, compared with that from $t d^{+}$mice. $\beta$-actin serves as loading control. Shown are representative blots. 1, 3, 5: samples from $t d^{+}$mice; 2, 4, 6: samples from Neo ${ }^{f / f}, t d^{+}$mice. Hypo, Hypothalamus; Pir, piriform cortex; Amyg, amygdala. $D, Q$ uantitative analysis of data in C. $n=3$ pairs of $t d^{+}$and $\mathrm{NeO}^{f / f}, t d^{+}$mice for Hypo and Pir groups; $n=4$ pairs for Amyg group. Paired Student's $t$ test: Hypo and Pir groups, $p>0.05 ;$ Amyg group, ${ }^{*} p<0.05$. $\boldsymbol{E}$, Diagram of the paired-recording configuration. Dark orange represents a $\mathrm{Cre}^{+}$pyramidal neuron. Cortical input pathway was stimulated. $\boldsymbol{F}$, Representative traces in BLA pyramidal neurons in response to current injection of -50 $\mathrm{pA}$ and $50 \mathrm{pA}$, respectively. Scale bars, $40 \mathrm{~ms}, 50 \mathrm{pA}$. G, Characterization of resting membrane potential (RMP) of pyramidal neurons. $n=6$ neuron pairs from $3 \mathrm{td}{ }^{+}$mice; $n=7$ neuron pairs from $3 \mathrm{Neo}^{f / f} ; t d^{+}$mice. Paired $t$ test: $p>0.05$. $\boldsymbol{H}$, Characterization of membrane input resistance (Rin) of pyramidal neurons. $n=6$ neuron pairs from $3 t d^{+}$mice; $n=7$ neuron pairs from 3 Neo ${ }^{f / f} ; t d^{+}$ mice. Student's $t$ test: $p>0.05$. I, Firing frequency was not altered by injecting 50 pA current. $n=6$ neuron pairs from $3 t d^{+}$mice; $n=7$ neuron pairs from 3 Neo ${ }^{t / f} ; t d^{+}$mice. Student's $t$ test: $p>0.05$.

thalamus (Hypo) or piriform cortex (Pir) of $\mathrm{Neo}^{\mathrm{f} / f} ; \mathrm{td}^{+}$mice, compared with that from $t d^{+}$mice (Fig. 7C,D; paired Student's $t$ test; for Hypo, $t_{(2)}=0.5065, p=0.6628$; for Pir, $t_{(2)}=0.9985$, $p=0.4232$; for amyg, $\left.t_{(3)}=5.127, p=0.0144\right)$, indicating accurate, reliable knockdown of Neogenin in BLA.

We first examined whether the effect of Neogenin deletion is cell-autonomous. Pairs of adjacent $\mathrm{Cre}^{+}$(red fluorescent with tdTomamto) and $\mathrm{Cre}^{-}$(nonfluorescent because of no dtTomato) excitatory neurons in BLA were recorded simultaneously for eEPSCs in response to the stimulation of cortical input pathway (Figs. 7E). Their excitatory neuron identities were confirmed by pyramidal shape and adapted firing frequency in response to positive current injection (Fig. $7 F$ ). We also compared the intrinsic properties of $\mathrm{Cre}^{+}$and $\mathrm{Cre}^{-}$neurons of different genotypes and found no difference in their resting membrane potential, membrane input resistance, or firing frequency in response to 50 pA current injections (Fig. 7G-I; paired Student's $t$ test; for $t d^{+}$in Fig. $7 G, t_{(5)}=0.5732, p=0.5913$; for $N e o^{f / f} ; t^{+}$in Fig. $7 G, t_{(6)}=$
0.3349, $p=0.7491$; for $t d^{+}$in Fig. $7 H, t_{(5)}=0.0179, p=0.9864$; for $\mathrm{Neo}^{f / f} ; \mathrm{td}^{+}$in Fig. $7 \mathrm{H}, t_{(6)}=0.8235, p=0.4417$; for $t d^{+}$in Fig. $7 I, t_{(5)}=0.3612, p=0.7327$; for $N e o^{f / f} ; t d^{+}$in Fig. $7 I, t_{(6)}=1.21$, $p=0.2718$ ). These observations suggest that neither Cre virus nor Neogenin deletion affects intrinsic excitability of excitatory neurons.

The excitatory synaptic strengths onto $\mathrm{Cre}^{+}$and $\mathrm{Cre}^{-}$neurons were then examined. To minimize the variation, we set eEPSC amplitudes of $\mathrm{Cre}^{-}$neurons between 100 and 200 pA by adjusting stimulation intensity (Fig. 8A). In $t d^{+}$mice, both AMPAR- and NMDAR-mediated EPSCs were similar between $\mathrm{Cre}^{+}$and Cre ${ }^{-}$neurons (Fig. $8 B, C$; paired Student's $t$ test; for $t d^{+}$in Fig. $8 B, t_{(10)}=1.549, p=0.1524$; for $t d^{+}$in Fig. $8 C, t_{(10)}=$ $0.3179, p=0.7571)$, indicating comparable synaptic strength between $\mathrm{Cre}^{+}$and $\mathrm{Cre}^{-}$neurons. However, in $\mathrm{NeO}^{f / f} ; \mathrm{td}^{+}$mice, AMPAR- and NMDAR-mediated EPSCs in $\mathrm{Cre}^{+}$neurons were markedly smaller than those in $\mathrm{Cre}^{-}$neurons (Fig. $8 B, C$; paired Student's $t$ test; for $\mathrm{Neo}^{f / f} ; \mathrm{td}^{+}$in Fig. $8 B, t_{(15)}=2.715, p=0.016$; 

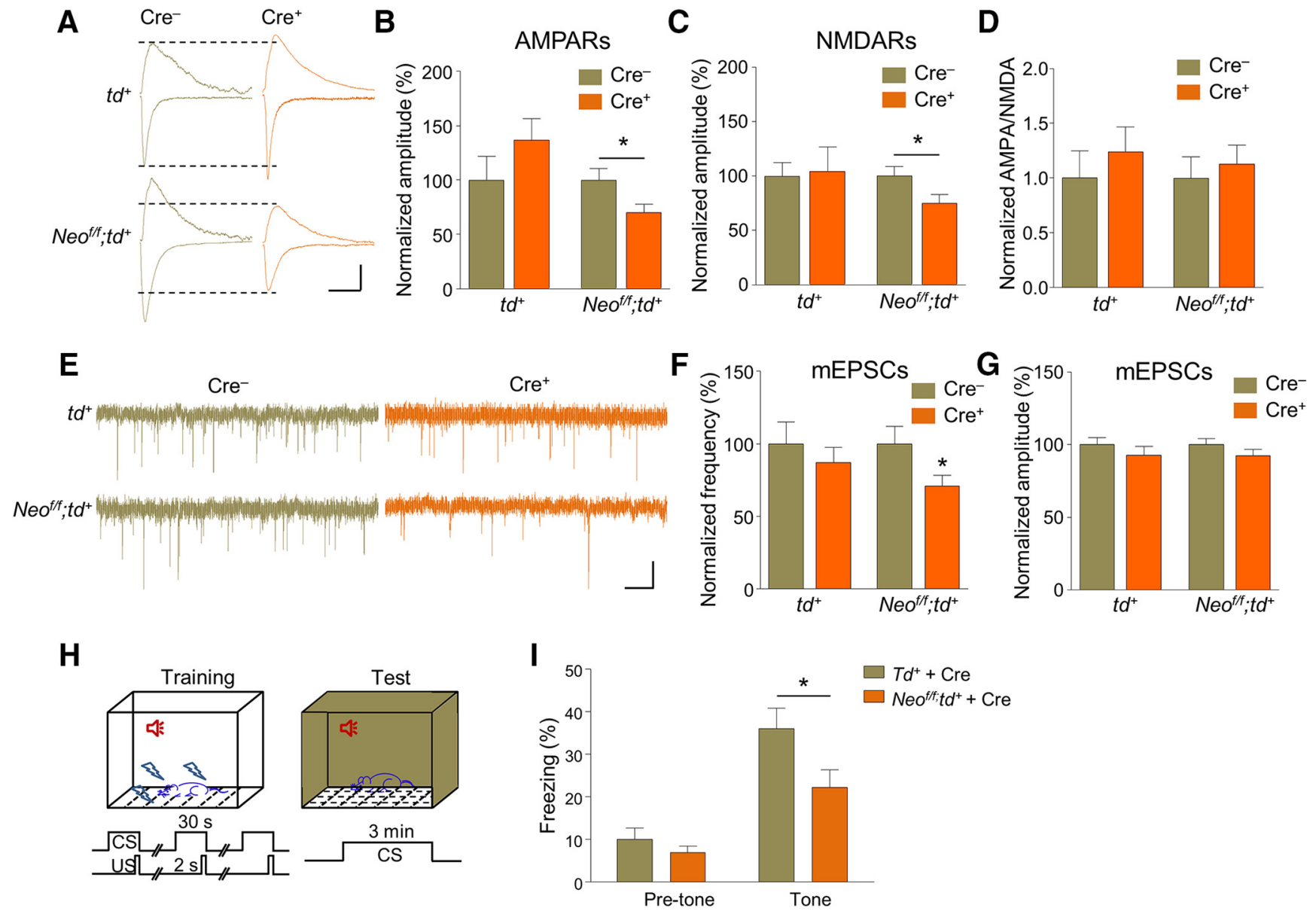

Figure 8. Neogenin in BLA neurons regulates excitatory synaptic transmission in a cell-autonomous manner. $\boldsymbol{A}$, Representative AMPARs (down) and NMDARs (up)-mediated EPSC traces recorded from $\mathrm{Cre}^{-} / \mathrm{Cre}^{+}$neuronal pairs in the BLA in $t d^{+}$and $\mathrm{Neo}^{\mathrm{fff}}, t d^{+}$mice injected with AAV-Cre-GFP virus. Scale bars, $40 \mathrm{~ms}, 50 \mathrm{pA}$. B, Quantification of AMPAR-mediated EPSC amplitude, which was normalized to the mean EPSC amplitude of Cre ${ }^{-}$neurons. $n=11$ pairs from $4 t d^{+}$mice; $n=16$ pairs from $5 \mathrm{Neo}^{f / f} ; t d^{+}$mice. Paired Student's $t$ test: ${ }^{*} p<0.05$. $C$, Quantification of NMDAR-mediated EPSC amplitude, which was normalized to the mean EPSC amplitude of Cre ${ }^{-}$neurons. $n=11$ pairs from $4 t d^{+}$mice; $n=15$ pairs from $5 \mathrm{Neo}^{f / f} ; t d^{+}$mice. Paired Student's $t$ test: ${ }^{*} p<0.05 . D$, Similar AMPA/NMDA ratios between $\mathrm{Cre}^{-}$and $\mathrm{Cre}^{+}$neurons in $t d^{+}$and $\mathrm{Neo}^{f / f} ; t d^{+}$mice. $n=9$ pairs from $4 t d^{+}$mice; $n=10$ pairs from $4 \mathrm{Neo}^{f f / ;} ; t d^{+}$mice. Paired Student's $t$ test: $p>0.05$. E, Representative mEPSC traces. Scale bars, $1 \mathrm{~s}, 10 \mathrm{pA}$. $\boldsymbol{F}$, Reduced mEPSC frequency in mutant mice. $n=9$ pairs from $4 t d^{+}$mice; $n=10$ pairs from 4 Neo ${ }^{t / f} ; t d^{+}$mice. Paired Student's $t$ test: for $t d^{+}$group, $p>0.05 ;$ for Neo ${ }^{f / f} ; t d^{+}$group, ${ }^{*} p<0.05$. G, Similar mEPSC amplitudes. $n=9$ pairs from $4 t d^{+}$mice; $n=10$ pairs from $4 \mathrm{Neo}^{f / f} ; t d^{+}$mice. Paired Student's $t$ test: $p>0.05$. $\boldsymbol{H}$, Diagram of tone-cued fear conditioning, as described above. $\boldsymbol{I}$, Reduced freezing time in the presence of tone in $\mathrm{Neo}^{\mathrm{fff}} ; \mathrm{td}^{+}$mice with Cre virus. $n=12$ mice for each group. Student's $t$ test: ${ }^{*} p<0.05$.

for $N e o^{f / f} ; t d^{+}$in Fig. $\left.8 C, t_{(14)}=2.653, p=0.0189\right)$, suggesting that Neogenin ablation decreased excitatory synaptic strength in a cell-autonomous manner.

The ratios of AMPAR current/NMDAR current (AMPA/ NMDA) were similar between $\mathrm{Cre}^{+}$and $\mathrm{Cre}^{-}$neurons in $t d^{+}$ and Neo ${ }^{f / f} ; t d^{+}$mice (Fig. $8 D$; paired Student's $t$ test; for $t d^{+}, t_{(8)}=$ $1.548, p=0.1602$; for $\left.N e o^{f / f} ; t d^{+}, t_{(9)}=0.577, p=0.5781\right)$, indicating that the AMPAR and NMDAR composition is not affected by Neogenin mutation. We also determined whether virusinduced Neogenin mutation alters mEPSCs of BLA pyramidal neurons. mEPSC frequency in $\mathrm{Cre}^{+}$neurons was comparable with that in $\mathrm{Cre}^{-}$neurons in $t d^{+}$mice (Fig. $8 E, F$; paired Student's $t$ test, $\left.t_{(7)}=1.237, p=0.2561\right)$. However, mEPSC frequency in $\mathrm{Neo}^{f / f} ; \mathrm{td}^{+}$mice was reduced, compared with control (Fig. $8 E, F$; paired Student's $t$ test, $t_{(7)}=2.636, p=0.0336$ ). No change was observed in mEPSC amplitudes (Fig. $8 G$; paired Student's $t$ test; for $t d^{+}, t_{(7)}=1.277, p=0.2423$; for $\mathrm{Neo}^{f / f} ; t d^{+}, t_{(7)}=$ $1.508, p=0.1752$ ). These results uncovered a role of Neogenin in maintaining excitatory synapses onto BLA pyramidal neurons and likely their functions in adult mice.
Finally, Cre virus-injected $\mathrm{Neo}^{f / f} ; t d^{+}$mice and control mice were subjected to tone-cued fear conditioning test (Fig. $8 H$ ). As shown in Figure 8I, freezing level of $\mathrm{Neo}^{f / f} ; \mathrm{td}^{+}$mice is remarkably reduced on the test day compared with control mice, suggesting that Neogenin reduction specifically in BLA impaired tone-cued fear memory (Student's $t$ test; for pretone, $t_{(22)}=0.9811, p=$ 0.3372 ; for tone, $\left.t_{(22)}=2.184, p=0.0399\right)$. Together, these observations demonstrated a critical role of Neogenin in the BLA for excitatory transmission and fear memory in adult mice.

\section{Discussion}

In this report, we identify an unrecognized function of Neogenin for information processing in amygdala. First, Neogenin is highly expressed in pyramidal neurons in the BLA region of amygdala. Second, mutating Neogenin in neural progenitor cells impairs fear memory in GFAP-Neo ${ }^{-1-}$ mice. Third, the number of $\mathrm{cFos}^{+}$ neurons in response to tone-cued fear training was reduced in mutant mice, indicating aberrant neuronal activation in the absence of Neogenin. Fourth, Neogenin mutation had no effect on the intrinsic excitability of BLA pyramidal neurons but caused 
downward shift of the I/O curve in response to cortical afferent fiber stimulation, indicating reduced cortical afferent input to these neurons. Fifth, both induction and maintenance of LTP were reduced, suggesting a role of Neogenin in synaptic plasticity. Sixth, Neogenin mutant mice showed a reduction in spine density that was associated with reduced mEPSC frequency, suggesting a role of Neogenin in forming excitatory synapses. Finally, ablating Neogenin in BLA of adult mice reduced mEPSC frequency and impaired fear memory. These results reveal a novel function of Neogenin in amygdala for information processing by promoting and maintaining neurotransmission and synaptic plasticity, and provide an insight into molecular mechanisms of neuronal activation in amygdala.

Being a homolog of DCC, Neogenin has been studied extensively for its role in neural development. Neogenin has shown to regulate neural tube formation and somitogenesis, neuronal survival, tangential migration, and astrogliogenesis (Matsunaga et al., 2004; Mawdsley et al., 2004; Fitzgerald et al., 2006; Huang et al., 2016). Unlike DCC, there is no evidence that Neogenin is involved in axon guidance. In agreement, Neogenin mutant mice exhibit apparently normal external capsules and posterior parts of anterior commissures. There appears to be no reduction in NeuN- and PV-positive neurons in the BLA. Neogenin is highly expressed in adult neuronal stem cells in subventricular zone and SGZ of dentate gyrus, regulating adult neurogenesis by promoting neuroblast migration, cell cycle exit in subventricular zone and maintaining stem cell proliferation and differentiation in SGZ, respectively (O'Leary et al., 2015; Sun et al., 2018).

At embryonic stage, Neogenin is present in neurogenic and gliogenic cells (Fitzgerald et al., 2007), suggesting a widespread expression in the brain. By taking advantage of the Neogenin reporter mouse line, in which $\beta$-gal expression is thought to faithfully indicate where Neogenin is expressed, we find that Neogenin is enriched in the BLA of amygdala. Costaining results indicated that Neogenin mostly expresses in excitatory neurons, but less in interneurons. In agreement, excitatory, but not inhibitory, synaptic transmission compromised in the absence of $\mathrm{NeO}$ genin.

cFos is widely used to mark activated cells in response to stimulations (Knapska et al., 2007). Aberrant neuronal activation in amygdala leads to impaired fear memory formation (Huang et al., 2014). Intriguingly, when Neogenin was mutated, $\mathrm{cFos}^{+}$neuron number was decreased following fear conditioning training. This result suggests that Neogenin serves as a positive regulator of neuronal activation in BLA, which is required for fear memory. Neogenin mutation has no effect on intrinsic excitability of pyramidal neurons in the BLA, but reduced eEPSCs in response to stimuli, with a suppressed I/O curve, suggesting compromised afferent input to BLA pyramidal neurons. In accord, LTP of BLA pyramidal neurons elicited by stimulating the cortical afferent pathway was also reduced in Neogenin mutant mice. However, these deficits were not due to a change in intrinsic excitability of BLA pyramidal neurons or change in glutamate receptors. Indeed, because both NMDAR-mediated synaptic currents and AMPAR-mediated synaptic currents were reduced (Fig. $8 B, C$ ), the ratio of AMPAR- and NMDAR-mediated components of cortico-BLA eEPSCs was not changed in neurons by Neogenin mutation. Reduction in either NMDAR- or AMPAR-mediated currents could impair LTP (Rouach et al., 2005; Ng et al., 2009; Levy et al., 2018). LTP could also be impaired when both NMDAR- and AMPAR-mediated currents are reduced (Chen et al., 2010; Tracy et al., 2016; Incontro et al., 2018). In the latter case, the AMPA/NMDA current ratio may not change.

We found that PPR, an indicator of glutamate release probability, was not altered by Neogenin mutation. Golgi staining revealed that the numbers of spines of BLA pyramidal neurons, in particular those of mushroom and thin spines, were reduced in Neogenin mutant mice. These results are in agreement with decreased mEPSC frequency in excitatory neurons with Neogenin mutation and suggest that Neogenin is critical for forming excitatory synapses onto BLA pyramidal neurons. Interestingly, Netrin-1, a known ligand of Neogenin, has been shown to promote excitatory synaptogenesis between cortical neurons by initiating synapse assembly (Goldman et al., 2013). DCC, a homologous protein of Neogenin, is also expressed in the adult brain and regulates spine size, learning memory, and LTP through Src activation (Horn et al., 2013). It is worthy studying whether Neogenin acts together with Netrin-1 and/or DCC to regulate spine development and/or synaptic plasticity. Intriguingly, ablating Neogenin in the BLA of adult mice also reduced mEPSC frequency and impaired fear memory, suggesting a role of Neogenin in maintaining excitatory synapses and their function.

The BLA can be subdivided into the lateral amygdala (LA) and basal amygdala (BA). The LA receives sensory inputs, including auditory, visual, and somatosensory inputs that convey information of conditioned and unconditioned stimuli (Sah et al., 2003). Projections from auditory and multimodal areas of the thalamus mediate short-latency, broadly tuned auditory responses, whereas projections from the ventral auditory cortex are responsible for transmitting information about more complex auditory stimuli (Tovote et al., 2015). Acquisition and expression of conditioned fear depend on associative plasticity in the LA. However, learned fear is mediated by coordinated activity among multiple brain regions. BA is connected reciprocally with other brain regions, including the PFC and ventral hippocampus, and also sends signals to the CeA that target the midbrain and hypothalamus to mediate moto and autonomic responses (LeDoux, 2000). The BLA is surrounded by a number of clusters of GABAergic neurons called intercalated cells. In Pavlovian fear conditioning, BLA and $\mathrm{CeA}$ are involved in acquisition, consolidation, and expression, and intercalated cells are for extinction (Phelps and LeDoux, 2005; Herry et al., 2010). The prelimbic and lateral limbic of the PFC are for fear expression and extinction, respectively (Izquierdo et al., 2016). Our study showed that Neogenin mutant mice are impaired in fear memory retrieval. Because Neogenin mutation reduces spine density and does not change PPR, this may indicate that the mutation affects spine development and maintenance of excitatory synapses onto BLA pyramidal neurons. It is likely that the fear memory impairment in mutant mice reflects the defect of general information processing in the BLA. It will be interesting in the future to investigate how fear memory is altered and to determine whether Neogenin is required for other functions of amygdala, such as other associative fear paradigms, including contextual fear, inhibitory avoidance, conditioned taste aversion; associative learning, including attention, reinforcement, and representation; and innate fear (Holland and Gallagher, 1999).

\section{References}

Bolton MM, Heaney CF, Sabbagh JJ, Murtishaw AS, Magcalas CM, Kinney JW (2012) Deficits in emotional learning and memory in an animal model of schizophrenia. Behav Brain Res 233:35-44. CrossRef Medline

Bradford D, Faull RL, Curtis MA, Cooper HM (2010) Characterization of the netrin/RGMa receptor neogenin in neurogenic regions of the mouse 
and human adult forebrain. J Comp Neurol 518:3237-3253. CrossRef Medline

Chen Y, Rex CS, Rice CJ, Dubé CM, Gall CM, Lynch G, Baram TZ (2010) Correlated memory defects and hippocampal dendritic spine loss after acute stress involve corticotropin-releasing hormone signaling. Proc Natl Acad Sci U S A 107:13123-13128. CrossRef Medline

De Vries M, Cooper HM (2008) Emerging roles for neogenin and its ligands in CNS development. J Neurochem 106:1483-1492. CrossRef Medline

Dong ZF, Tang LJ, Deng GF, Zeng T, Liu SJ, Wan RP, Liu T, Zhao QH, Yi YH, Liao WP, Long YS (2014) Transcription of the human sodium channel SCN1A gene is repressed by a scaffolding protein RACK1. Mol Neurobiol 50:438-448. CrossRef Medline

Fitzgerald DP, Cole SJ, Hammond A, Seaman C, Cooper HM (2006) Characterization of neogenin-expressing neural progenitor populations and migrating neuroblasts in the embryonic mouse forebrain. Neuroscience 142:703-716. CrossRef Medline

Fitzgerald DP, Bradford D, Cooper HM (2007) Neogenin is expressed on neurogenic and gliogenic progenitors in the embryonic and adult central nervous system. Gene Expr Patterns 7:784-792. CrossRef Medline

Goldman JS, Ashour MA, Magdesian MH, Tritsch NX, Harris SN, Christofi N, Chemali R, Stern YE, Thompson-Steckel G, Gris P, Glasgow SD, Grutter P, Bouchard JF, Ruthazer ES, Stellwagen D, Kennedy TE (2013) Netrin-1 promotes excitatory synaptogenesis between cortical neurons by initiating synapse assembly. J Neurosci 33:17278-17289. CrossRef Medline

Herry C, Ferraguti F, Singewald N, Letzkus JJ, Ehrlich I, Lüthi A (2010) Neuronal circuits of fear extinction. Eur J Neurosci 31:599-612. CrossRef Medline

Holland PC, Gallagher M (1999) Amygdala circuitry in attentional and representational processes. Trends Cogn Sci 3:65-73. CrossRef Medline

Hong M, Schachter KA, Jiang G, Krauss RS (2012) Neogenin regulates sonic hedgehog pathway activity during digit patterning. Dev Dyn 241:627637. CrossRef Medline

Horn KE, Glasgow SD, Gobert D, Bull SJ, Luk T, Girgis J, Tremblay ME, McEachern D, Bouchard JF, Haber M, Hamel E, Krimpenfort P, Murai KK, Berns A, Doucet G, Chapman CA, Ruthazer ES, Kennedy TE (2013) DCC expression by neurons regulates synaptic plasticity in the adult brain. Cell Rep 3:173-185. CrossRef Medline

Huang TN, Chuang HC, Chou WH, Chen CY, Wang HF, Chou SJ, Hsueh YP (2014) Tbr1 haploinsufficiency impairs amygdalar axonal projections and results in cognitive abnormality. Nat Neurosci 17:240-247. CrossRef Medline

Huang Z, Sun D, Hu JX, Tang FL, Lee DH, Wang Y, Hu G, Zhu XJ, Zhou J, Mei L, Xiong WC (2016) Neogenin promotes BMP2 activation of YAP and Smad1 and enhances astrocytic differentiation in developing mouse neocortex. J Neurosci 36:5833-5849. CrossRef Medline

Incontro S, Díaz-Alonso J, Iafrati J, Vieira M, Asensio CS, Sohal VS, Roche KW, Bender KJ, Nicoll RA (2018) The CaMKII/NMDA receptor complex controls hippocampal synaptic transmission by kinase-dependent and independent mechanisms. Nat Commun 9:2069. CrossRef Medline

Izquierdo I, Furini CR, Myskiw JC (2016) Fear memory. Physiol Rev 96: 695-750. CrossRef Medline

Kang JS, Yi MJ, Zhang W, Feinleib JL, Cole F, Krauss RS (2004) Netrins and neogenin promote myotube formation. J Cell Biol 167:493-504. CrossRef Medline

Kee N, Wilson N, De Vries M, Bradford D, Key B, Cooper HM (2008) Neogenin and RGMa control neural tube closure and neuroepithelial morphology by regulating cell polarity. J Neurosci 28:12643-12653. CrossRef Medline

Kim J, Kwon JT, Kim HS, Josselyn SA, Han JH (2014) Memory recall and modifications by activating neurons with elevated CREB. Nat Neurosci 17:65-72. CrossRef Medline

Knapska E, Radwanska K, Werka T, Kaczmarek L (2007) Functional internal complexity of amygdala: focus on gene activity mapping after behavioral training and drugs of abuse. Physiol Rev 87:1113-1173. CrossRef Medline

Kuns-Hashimoto R, Kuninger D, Nili M, Rotwein P (2008) Selective binding of RGMc/hemojuvelin, a key protein in systemic iron metabolism, to BMP-2 and neogenin. Am J Physiol Cell Physiol 294:C994-C1003. CrossRef Medline

LeDoux JE (2000) Emotion circuits in the brain. Annu Rev Neurosci 23: 155-184. CrossRef Medline
Lee DH, Zhou LJ, Zhou Z, Xie JX, Jung JU, Liu Y, Xi CX, Mei L, Xiong WC (2010) Neogenin inhibits HJV secretion and regulates BMP-induced hepcidin expression and iron homeostasis. Blood 115:3136-3145. CrossRef Medline

Levy AD, Xiao X, Shaw JE, Sudarsana Devi SP, Katrancha SM, Bennett AM, Greer CA, Howe JR, Machida K, Koleske AJ (2018) Noonan syndromeassociated SHP2 dephosphorylates GluN2B to regulate NMDA receptor function. Cell Rep 24:1523-1535. CrossRef Medline

Liu ZP, He QH, Pan HQ, Xu XB, Chen WB, He Y, Zhou J, Zhang WH, Zhang JY, Ying XP, Han RW, Li BM, Gao TM, Pan BX (2017) Delta subunitcontaining gamma-aminobutyric acid A receptor disinhibits lateral amygdala and facilitates fear expression in mice. Biol Psychiatry 81:9901002. CrossRef Medline

Lu Y, Sun XD, Hou FQ, Bi LL, Yin DM, Liu F, Chen YJ, Bean JC, Jiao HF, Liu X, Li BM, Xiong WC, Gao TM, Mei L (2014) Maintenance of GABAergic activity by neuregulin 1-ErbB4 in amygdala for fear memory. Neuron 84:835-846. CrossRef Medline

Madisen L, Zwingman TA, Sunkin SM, Oh SW, Zariwala HA, Gu H, Ng LL, Palmiter RD, Hawrylycz MJ, Jones AR, Lein ES, Zeng H (2010) A robust and high-throughput cre reporting and characterization system for the whole mouse brain. Nat Neurosci 13:133-140. CrossRef Medline

Maren S (2001) Neurobiology of pavlovian fear conditioning. Annu Rev Neurosci 24:897-931. CrossRef Medline

Matsumoto Y, Irie F, Inatani M, Tessier-Lavigne M, Yamaguchi Y (2007) Netrin-1/DCC signaling in commissural axon guidance requires cellautonomous expression of heparan sulfate. J Neurosci 27:4342-4350. CrossRef Medline

Matsunaga E, Tauszig-Delamasure S, Monnier PP, Mueller BK, Strittmatter SM, Mehlen P, Chédotal A (2004) RGM and its receptor neogenin regulate neuronal survival. Nat Cell Biol 6:749-755. CrossRef Medline

Mawdsley DJ, Cooper HM, Hogan BM, Cody SH, Lieschke GJ, Heath JK (2004) The netrin receptor neogenin is required for neural tube formation and somitogenesis in zebrafish. Dev Biol 269:302-315. CrossRef Medline

McDonald AJ (1996) Glutamate and aspartate immunoreactive neurons of the rat basolateral amygdala: colocalization of excitatory amino acids and projections to the limbic circuit. J Comp Neurol 365:367-379. CrossRef Medline

McGaugh JL (2004) The amygdala modulates the consolidation of memories of emotionally arousing experiences. Annu Rev Neurosci 27:1-28. CrossRef Medline

Mitchell KJ, Pinson KI, Kelly OG, Brennan J, Zupicich J, Scherz P, Leighton PA, Goodrich LV, Lu X, Avery BJ, Tate P, Dill K, Pangilinan E, Wakenight P, Tessier-Lavigne M, Skarnes WC (2001) Functional analysis of secreted and transmembrane proteins critical to mouse development. Nat Genet 28:241-249. CrossRef Medline

Ng D, Pitcher GM, Szilard RK, Sertié A, Kanisek M, Clapcote SJ, Lipina T, Kalia LV, Joo D, McKerlie C, Cortez M, Roder JC, Salter MW, McInnes RR (2009) Netol is a novel CUB-domain NMDA receptor-interacting protein required for synaptic plasticity and learning. PLoS Biol 7:e41. CrossRef Medline

O'Leary CJ, Bradford D, Chen M, White A, Blackmore DG, Cooper HM (2015) The Netrin/RGM receptor, Neogenin, controls adult neurogenesis by promoting neuroblast migration and cell cycle exit. Stem Cells 33:503-514. CrossRef Medline

Olsson A, Phelps EA (2007) Social learning of fear. Nat Neurosci 10:10951102. CrossRef Medline

Ou Z, Kong X, Sun X, He X, Zhang L, Gong Z, Huang J, Xu B, Long D, Li J, Li Q, Xu L, Xuan A (2018) Metformin treatment prevents amyloid plaque deposition and memory impairment in APP/PS1 mice. Brain Behav Immun 69:351-363. CrossRef Medline

Parsons RG, Ressler KJ (2013) Implications of memory modulation for post-traumatic stress and fear disorders. Nat Neurosci 16:146-153. CrossRef Medline

Phelps EA, LeDoux JE (2005) Contributions of the amygdala to emotion processing: from animal models to human behavior. Neuron 48:175-187. CrossRef Medline

Rajagopalan S, Deitinghoff L, Davis D, Conrad S, Skutella T, Chedotal A, Mueller BK, Strittmatter SM (2004) Neogenin mediates the action of repulsive guidance molecule. Nat Cell Biol 6:756-762. CrossRef Medline

Rouach N, Byrd K, Petralia RS, Elias GM, Adesnik H, Tomita S, Karimzadegan S, Kealey C, Bredt DS, Nicoll RA (2005) TARP gamma-8 controls 
hippocampal AMPA receptor number, distribution and synaptic plasticity. Nat Neurosci 8:1525-1533. CrossRef Medline

Sah P, Faber ES, Lopez De Armentia M, Power J (2003) The amygdaloid complex: anatomy and physiology. Physiol Rev 83:803-834. CrossRef Medline

Serafini T, Colamarino SA, Leonardo ED, Wang H, Beddington R, Skarnes WC, Tessier-Lavigne M (1996) Netrin-1 is required for commissural axon guidance in the developing vertebrate nervous system. Cell 87:10011014. CrossRef Medline

Sun D, Sun XD, Zhao L, Lee DH, Hu JX, Tang FL, Pan JX, Mei L, Zhu XJ, Xiong WC (2018) Neogenin, a regulator of adult hippocampal neurogenesis, prevents depressive-like behavior. Cell Death Dis 9:8. CrossRef Medline

Sun XD, Li L, Liu F, Huang ZH, Bean JC, Jiao HF, Barik A, Kim SM, Wu H, Shen C, Tian Y, Lin TW, Bates R, Sathyamurthy A, Chen YJ, Yin DM, Xiong L, Lin HP, Hu JX, Li BM, et al. (2016) Lrp4 in astrocytes modulates glutamatergic transmission. Nat Neurosci 19:1010-1018. CrossRef Medline

Tamamaki N, Yanagawa Y, Tomioka R, Miyazaki J, Obata K, Kaneko T (2003) Green fluorescent protein expression and colocalization with calretinin, parvalbumin, and somatostatin in the GAD67-GFP knock-in mouse. J Comp Neurol 467:60-79. CrossRef Medline

Torregrossa MM, Corlett PR, Taylor JR (2011) Aberrant learning and memory in addiction. Neurobiol Learn Mem 96:609-623. CrossRef Medline

Tovote P, Fadok JP, Lüthi A (2015) Neuronal circuits for fear and anxiety. Nat Rev Neurosci 16:317-331. CrossRef Medline

Tracy TE, Sohn PD, Minami SS, Wang C, Min SW, Li Y, Zhou Y, Le D, Lo I, Ponnusamy R, Cong X, Schilling B, Ellerby LM, Huganir RL, Gan L (2016) Acetylated tau obstructs KIBRA-mediated signaling in synaptic plasticity and promotes tauopathy-related memory loss. Neuron 90:245260. CrossRef Medline

van den Heuvel DM, Hellemons AJ, Pasterkamp RJ (2013) Spatiotemporal expression of repulsive guidance molecules (RGMs) and their receptor neogenin in the mouse brain. PLoS One 8:e55828. CrossRef Medline
Vielmetter J, Kayyem JF, Roman JM, Dreyer WJ (1994) Neogenin, an avian cell surface protein expressed during terminal neuronal differentiation, is closely related to the human tumor suppressor molecule deleted in colorectal cancer. J Cell Biol 127:2009-2020. CrossRef Medline

Wan RP, Zhou LT, Yang HX, Zhou YT, Ye SH, Zhao QH, Gao MM, Liao WP, Yi YH, Long YS (2017) Involvement of FMRP in primary microRNA processing via enhancing drosha translation. Mol Neurobiol 54:25852594. CrossRef Medline

Wang YN, Figueiredo D, Sun XD, Dong ZQ, Chen WB, Cui WP, Liu F, Wang HS, Li HW, Robinson H, Fei EK, Pan BX, Li BM, Xiong WC, Mei L (2018) Controlling of glutamate release by neuregulin3 via inhibiting the assembly of the SNARE complex. Proc Natl Acad Sci U S A 115:25082513. CrossRef Medline

Xu K, Wu Z, Renier N, Antipenko A, Tzvetkova-Robev D, Xu Y, Minchenko M, Nardi-Dei V, Rajashankar KR, Himanen J, Tessier-Lavigne M, Nikolov DB (2014) Neural migration. structures of netrin-1 bound to two receptors provide insight into its axon guidance mechanism. Science 344:1275-1279. CrossRef Medline

Zhang L, Liang Z, Zhu P, Li M, Yi YH, Liao WP, Su T (2016) Altered intrinsic properties and bursting activities of neurons in layer IV of somatosensory cortex from fmr-1 knockout mice. Exp Neurol 280:60-69. CrossRef Medline

Zhang X, He X, Li Q, Kong X, Ou Z, Zhang L, Gong Z, Long D, Li J, Zhang M, Ji W, Zhang W, Xu L, Xuan A (2017) PI3K/AKT/mTOR signaling mediates valproic acid-induced neuronal differentiation of neural stem cells through epigenetic modifications. Stem Cell Reports 8:1256-1269. CrossRef Medline

Zhou Z, Xie J, Lee D, Liu Y, Jung J, Zhou L, Xiong S, Mei L, Xiong WC (2010) Neogenin regulation of BMP-induced canonical smad signaling and endochondral bone formation. Dev Cell 19:90-102. CrossRef Medline

Zhuo L, Theis M, Alvarez-Maya I, Brenner M, Willecke K, Messing A (2001) hGFAP-cre transgenic mice for manipulation of glial and neuronal function in vivo. Genesis 31:85-94. CrossRef Medline 